

\title{
Equid use and provision during the Early Iron Age in Can Roqueta (NE Iberian Peninsula). Zooarchaeological study and first strontium isotope result $(87 \mathrm{Sr} / 86 \mathrm{Sr})$
}

S. Albizuri, S. Valenzuela-Lamas, Delphine Bosch, M. Fernandez, F.J. López-Cachero

\section{To cite this version:}

S. Albizuri, S. Valenzuela-Lamas, Delphine Bosch, M. Fernandez, F.J. López-Cachero. Equid use and provision during the Early Iron Age in Can Roqueta (NE Iberian Peninsula). Zooarchaeological study and first strontium isotope result (87Sr/86Sr). Journal of Archaeological Science: Reports, 2019, 26, pp.101907. 10.1016/j.jasrep.2019.101907 . hal-02391866

\section{HAL Id: hal-02391866 https://hal.science/hal-02391866}

Submitted on 21 Nov 2020

HAL is a multi-disciplinary open access archive for the deposit and dissemination of scientific research documents, whether they are published or not. The documents may come from teaching and research institutions in France or abroad, or from public or private research centers.
L'archive ouverte pluridisciplinaire $\mathbf{H A L}$, est destinée au dépôt et à la diffusion de documents scientifiques de niveau recherche, publiés ou non, émanant des établissements d'enseignement et de recherche français ou étrangers, des laboratoires publics ou privés. 


\title{
Equid use and provision during the Early Iron Age in Can Roqueta (NE Iberian Peninsula). Zooarchaeological study and first strontium isotope result $\left({ }^{87} \mathrm{Sr} /{ }^{86} \mathrm{Sr}\right)$
}

\author{
S. Albizuri ${ }^{\mathrm{a}, *}$, S. Valenzuela-Lamas ${ }^{\mathrm{b}}$, D. Bosch ${ }^{\mathrm{c}}$, M. Fernandez ${ }^{\mathrm{d}}$, F.J. López-Cachero ${ }^{\mathrm{e}}$ \\ ${ }^{a}$ Universitat de Barcelona, Departament d'Història i Arqueologia-SERP, C/Montalegre 6-8, 08001 Barcelona, Spain \\ ${ }^{\mathrm{b}}$ Consejo Superior de Investigaciones Científicas - Institució Milà i Fontanals, C/Egipcíaques 15, 08001 Barcelona, Spain \\ ${ }^{\mathrm{c}}$ Laboratoire Géosciences, CNRS-Université Montpellier, UMR-5243, 34095 Montpellier, France \\ d 608 Farm And Equine Veterinary Surgeons, Quarry Farm, Rowington Green, Rowington, Warwick, Warwickshire, UK \\ ${ }^{\mathrm{e}}$ Universitat de Barcelona, Departament d'Història i Arqueologia-SERP, C/Montalegre 6-8, 08001 Barcelona, Spain
}

\section{A R T I C L E I N F O}

\section{Keywords:}

Equids

Mobility

Early Iron Age

Iberian Peninsula

Strontium isotopes

\begin{abstract}
A B S T R A C T
This article reports the results of a zooarchaeological study (including, mortality profiles, and anatomical and pathological descriptions) of the Early Iron Age (8th-6th c. BCE) equid remains at the Can Roqueta site (Sabadell, Barcelona), together with the first strontium isotope results to determine their geographical origin. The zooarchaeological study reveals a remarkable number of equid remains at the site, the bone pathologies of which suggest their use for riding, drafting and load carrying. The mortality and sex profiles point to the presence of adult animals, while the absence of neonatal and juvenile remains raises the question as to whether these individuals may have originated from other sites specialised in equid breeding. The strontium values obtained from six individuals suggest that some equids were reared in a geological area with a similar strontium signature to that of the Vallès area, where the site is located. However, three equids present a different strontium signature, pointing to a possibly different geographical origin.
\end{abstract}

\section{Introduction}

Horses differ from other domesticates in terms of both their symbolic and economic value. This may be related to their care, feeding or training requirements, all of which are usually much more complex than those of other domesticates (e.g. cattle, sheep, pigs and dogs). Their work force value, slow growth, and low meat weight compared to that of other domesticates means horses have not usually been exploited for food (meat or milk) in the Iberian Peninsula.

In the northern half of the Iberian Peninsula, horse remains in domestic waste contexts have appeared sporadically in some 3rd and 2nd millennium BCE settlements (for details, see Alcalde et al., 1997; Alonso et al., 2002; Legge, 1994; Nieto et al., 2016), but their presence does not become widespread until the 12th century BCE (i.e. Late Bronze Age) (Albizuri, 2014; Albizuri, 2018; Albizuri et al., 2011). However, it is not until the Early Iron Age (8th-6th c. BCE), that the first archaeological evidence of horse remains and iron bits are documented in funerary zones and ritual structures, as in Can Roqueta (Albizuri, 2014; López Cachero et al., in press).
Horse taming and breeding require specialised knowledge and considerable economic investment before the animals can be put to use. Given the difficulties of equid breeding and training, as well as their value for light transport, the existence of specialised horse breeding sites in Europe during Late Prehistory has been suggested (Bendrey et al., 2009; Bendrey, 2010; Grant, 1984; Harcourt, 1979). Only two sites in NE Iberia present signs of equid breeding, as evidenced by foetal remains registered - that is, Vilars d'Arbeca and Tossal del Molinet (see Gómez, 2003; Nieto et al., 2010 for details) -. The fact of finding few horse foetuses is already very significant and today it is the only clear evidence of equid breeding during the Early Iron Age in this area. At this time, the mobility of both human and animal populations in Europe is clearly visible in the isotope evidence recovered from certain areas (Bendrey et al., 2017; Bendrey et al., 2009; Gerling, 2015; Makarewicz et al., 2018; Nuviala et al., 2014). Concurrent with this, there was a growth in commercial networks and territoriality as well as an increasing social differentiation, something that was especially evident in tombs associated with horse remains (Albizuri et al., 2016a; Gerling, 2015; Kmetová, 2017; López Cachero, 2007). All this raises important

\footnotetext{
* Corresponding author.

E-mail addresses: silvia.albizuri@upc.edu (S. Albizuri), svalenzuela@imf.csic.es (S. Valenzuela-Lamas), Delphine.Bosch@gm.univ-montp2.fr (D. Bosch), xavierlopez@ub.edu (F.J. López-Cachero).
} 
questions about the economic specialisation of certain settlements, about mobility and trade in this period, and about the growing importance of the horse at a time when social differentiation, militarisation and territoriality were increasing (Beylier, 2012; Dedet and Marchand, 2016; Gruat and Garcia, 2016; López-Cachero, 2014).

\section{Aims of study}

We analysed an unusual and important number of equid remains to increase scientific knowledge about the breeding and use of these animals at the site of Can Roqueta (Barcelona) during the Early Iron Age. The importance of Can Roqueta resides in the fact that it records the greatest number of equid remains so far in this area and period, and thus allows us to raise new questions about the breeding of these animals in NE Iberia, where equid remains are very scarce. The zooarchaeological study highlights the absolute predominance of adult animals. In addition, the absence of neonatal and juvenile remains raises the question as to whether these animals were the result of local breeding and taming or, on the contrary, whether they originated from other settlements that specialised in horse breeding. For this reason, and to assess the geographic range of horse provisioning, we performed a pilot strontium isotope study on six individuals.

\section{Materials and archaeological context}

\subsection{The site of Can Roqueta}

The archaeological site of Can Roqueta is located in Sabadell, about $25 \mathrm{~km}$ to the north of Barcelona. The site lies in the northeast margin of the Catalan Coastal Depression (Vallès-Penedès Depression), a valley forming a natural corridor parallel to the Catalan coast (Fig. 1).

The geology of the Vallès-Penedès Depression is characterised by fragmented outcrops of mainly Mesozoic and Tertiary sedimentary formations overlying infra-Silurian and Varingian batholith and other Palaeozoic metamorphic rocks (Santanach et al., 2011). The site occupies an area of about $2.5 \mathrm{~km}^{2}$ of distinct geological formations: thus, the sectors of 'Can Revella' (CRV), 'Diasa' (CR) and 'Can Roqueta II' (CRII) lie on Pleistocene alluvial fan sediments, while the sector of 'Torre Romeu' (CRTR) lies on sandstones, clays and limestones dated from the Lower Miocene (Fig. 2). In the vicinity of the site, within $10-15 \mathrm{~km}$, other sedimentary (Triassic sandstones, dolomites, limestones and marls) and metamorphic (Cambro-Ordovician Micacitic slates) formations outcrop. Finally, to the northeast, an extensive outcrop of Late Hercynian biotitic granodiorite is also present (Fig. 2).

The settlement was first excavated at the end of the 1980s, with the site's most relevant areas being associated with the large cremation necropolis of 'Can Piteu' (Carlús et al., 2007) (Fig. 1). Since then, > 2700 structures have been excavated, dating from the ancient Neolithic to present times, although most date from the Late Bronze Age (1300-750 cal BCE) and the Early Iron Age (750-550 cal BCE) (Fig. 1). In general, the best preserved structures are those found in the sediment, among which we find both cremation tombs and silos.

Evidence of equid remains are first attested to in different sectors of the archaeological site of Can Roqueta during the Late Bronze Age (1200 BCE). At this time, equids represent $5 \%$ of domesticates (NISP counts). In the Early Iron Age layers, there is a considerable increase in horse remains, representing up to $10 \%$ of all domesticates (Albizuri et al., 2011; Albizuri, 2014).

The zooarchaeological analysis of this Early Iron Age phase facilitated the identification of a minimum number of 46 individuals, most with caballine characteristics. Of this set, 39 individuals (MNI) were deposited in 28 structures mixed with other bone groups as for practices (López Cachero et al., in press). The deposits are mainly located in silos and pits, and in some cases in association with funerary structures. At Can Roqueta, the horse remains are often non-fractured and never found in association with domestic waste.

The taphonomy of the remains reveals several types of intentional accumulations of horse bones. The anatomical selection includes skulls and jaws, pelvis, scapulae, distal limb bones and, in some cases, bone segments appear in anatomical connection. On occasion, isolated bones (teeth, vertebrae, carpal/tarsal bones, metapodials and phalanges) were deposited. Finally, two complete skeletons (CR6 and CRII811, see Table 1) were found fully or partially articulated, with clear signs of anthropic manipulation. Moreover, horse bones appear in two the human burials (Albizuri et al., 2016a).

\subsection{Materials}

We have selected the best-preserved equids remains available. Twenty-two dated in Early Iron Age samples for osteometric study (Table 1) and six equid's teeth and two present-day evergreen oak leaves (Quercus cerrioides) for isotopic analysis (Table 2).

\section{Methods of analysis}

\subsection{Osteoarchaeological analysis}

The osteological similarity between horses and donkeys, as well as the diversity of characters among their hybrids, makes it difficult to differentiate Early Iron Age equids, especially as the archaeological evidence suggests that domestic horses (Equus caballus) and domestic asses (Equus asinus) were already present in the Iberian Peninsula. During the Early Iron Age there are no known cases of wild equids in NE Iberia, but their presence cannot fully be excluded as a possible factor contributing to the variability in equid sizes.

Traditionally, the introduction of the domestic ass is associated with the arrival of the Phoenicians and dated to around the 8th c. BCE in the eastern and southern Iberian Peninsula (Nadal et al., 2010). At present, we have no clear evidence of the production of hybrids in the Iberian Peninsula, although they have been recorded from the end of the 2nd millennium BCE in the Near East (Michel, 2004). Additionally, in present-day Catalonia there are cases of deposits bearing a clear Phoenician influence - including, for example, the "small equids" of Hort d'en Grimau and Aldovesta - that raise doubts about their classification as either donkeys or horses (or hybrids?) (Albizuri and Nadal, 1990; Albizuri et al., 2016b; Nadal et al., 2010).

Given the considerable likelihood of finding different equid species among the sample analysed, the zooarchaeological study focused specifically on distinguishing between them.

In this first work we prioritized the specimens that provided more information about the age, the morphometric characteristics and the pathologies that explain its possible use (see Table 1).

Morphological and osteometric studies were conducted on the tooth remains, scapulae, humerii, radii, metacarpals, femurs, tibias, metatarsals, taluses and proximal phalanges, in accordance with the various criteria and methods described in the literature (Barone, 1976; Davis, 1980; Eisenmann, 1979, 1980, 1981, 1984; Eisenmann and Beckouche, 1986; Johnstone, 2004). The biometric study was conducted in line with the protocols devised by Von den Driesch (1976) and Eisenmann (2009). Withers heights were calculated according to the greatest length (GL) of all bones in accordance with the factors proposed by May (1985) (in Johnstone, 2004). The shape index (SD $\times 100 / G L)$ was calculated using the smallest midshaft width (SD) and the greatest length of metacarpals, metatarsals, tibias and radii in order to estimate 


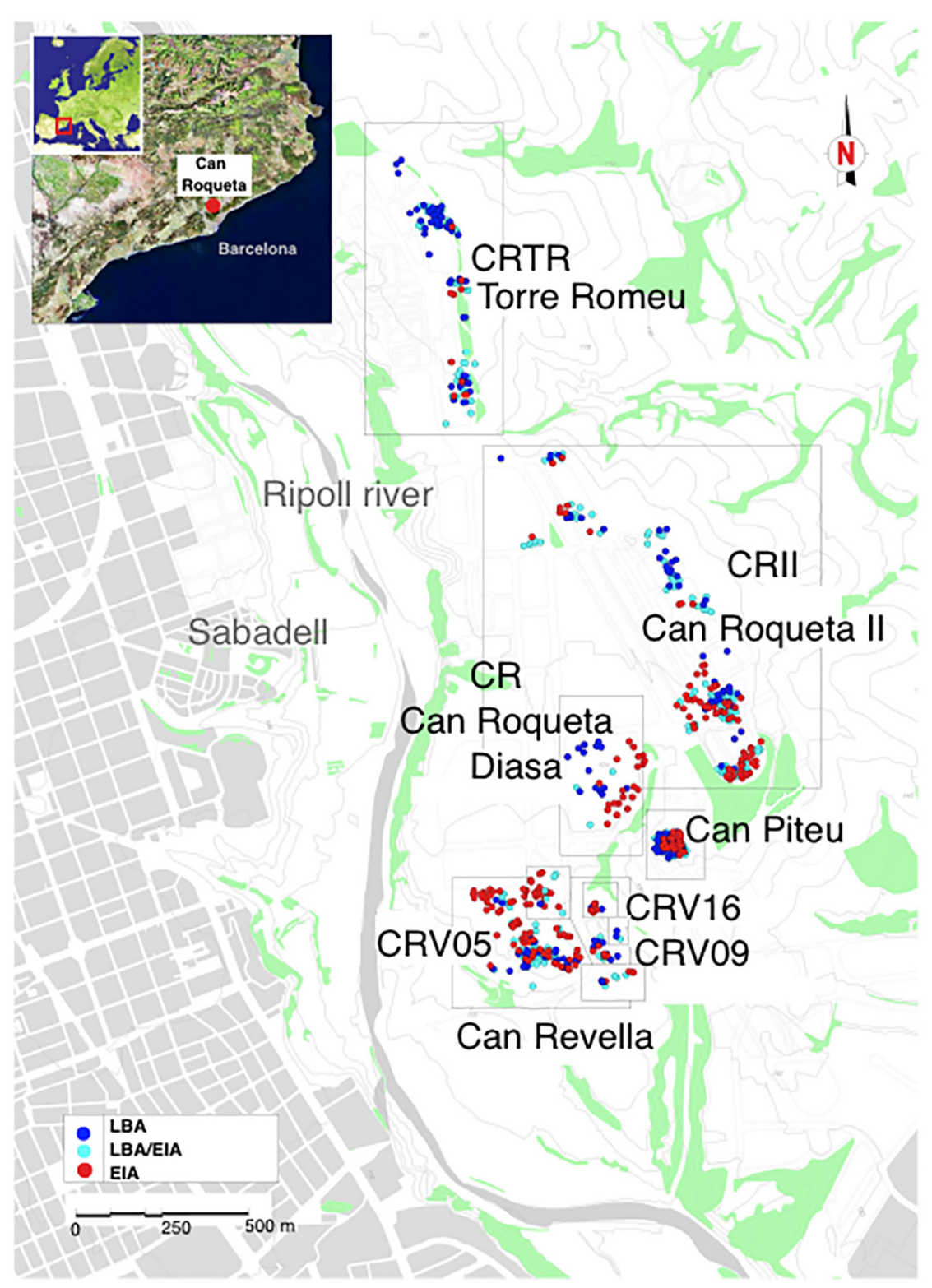

Fig. 1. Site location. Can Roqueta archaeological sectors.

ages of epiphyseal closure (Barone, 1976). Sex identification was based on morphology study of the pubis bone (Barone, 1976) and the presence/absence of canines. If canines were not present, we considered the individual to be female; when canines were well developed, we identified the individual as male. In intermediate cases (rudimentary canines), sexual attribution was not made, as both sexes can develop rudimentary canines. When there is no anatomical connection, sex is defined in accordance with cranial criteria (see Table 1).

The MNI was estimated in each structure by combining the best represented anatomical element and the age of the individuals and their general morphology (Poplin, 1976). Bone and teeth pathologies were determined by equine veterinarian specialists (MF) at 608 Farm and Equine Veterinary Surgeons (UK) and by reference to specific scholars (Bendrey, 2007b; Brown and Anthony, 1998; Cook and Strasser, 2003).

To guarantee the accurate chronological assignment of the equids, most individuals were radiocarbon dated. This was particularly the case for those in which the associated archaeological material was not chronologically characteristic (see Tables 1,2 ).

\subsection{Strontium isotope analysis}

Strontium isotopes $\left({ }^{87} \mathrm{Sr} /{ }^{86} \mathrm{Sr}\right)$ from tooth enamel provide direct evidence of geographical origins and, hence, of patterns of human and animal mobility. Consequently, they enable us to determine whether the animals were raised locally or rather they were 'imported' from other areas (e.g. Balasse et al., 2002; Bendrey et al., 2009; Evans et al., 2007; Minniti et al., 2014; Viner et al., 2010). Sr isotope ratio $\left({ }^{87} \mathrm{Sr} /{ }^{86} \mathrm{Sr}\right)$ varies from one geological formation to another depending on the age, the lithology of the considered rocks (schematically basic or felsic) and the original rubidium (Rb) content of the bedrock (Bentley, 2006): the older a rock formation and the higher proportion of ${ }^{87} \mathrm{Sr}$ compared to that of ${ }^{86} \mathrm{Sr}$. This is because ${ }^{87} \mathrm{Rb}$ decays into ${ }^{87} \mathrm{Sr}$ over time (Faure and Mensing, 2005). Similarly independently of the age of the rock, the more felsic a rock is the higher the ${ }^{87} \mathrm{Sr} /{ }^{86} \mathrm{Sr}$ ratio.

The ${ }^{87} \mathrm{Sr} /{ }^{86} \mathrm{Sr}$ isotope composition of skeletal material derives from the food and drink ingested by the animal, with strontium substituting calcium in the minerals of the skeletal tissue (Comar et al., 1957; Toots and Voorhies, 1965). Here, teeth are particularly valuable, as the isotopic signature of enamel bioapatite persists with few subsequent 


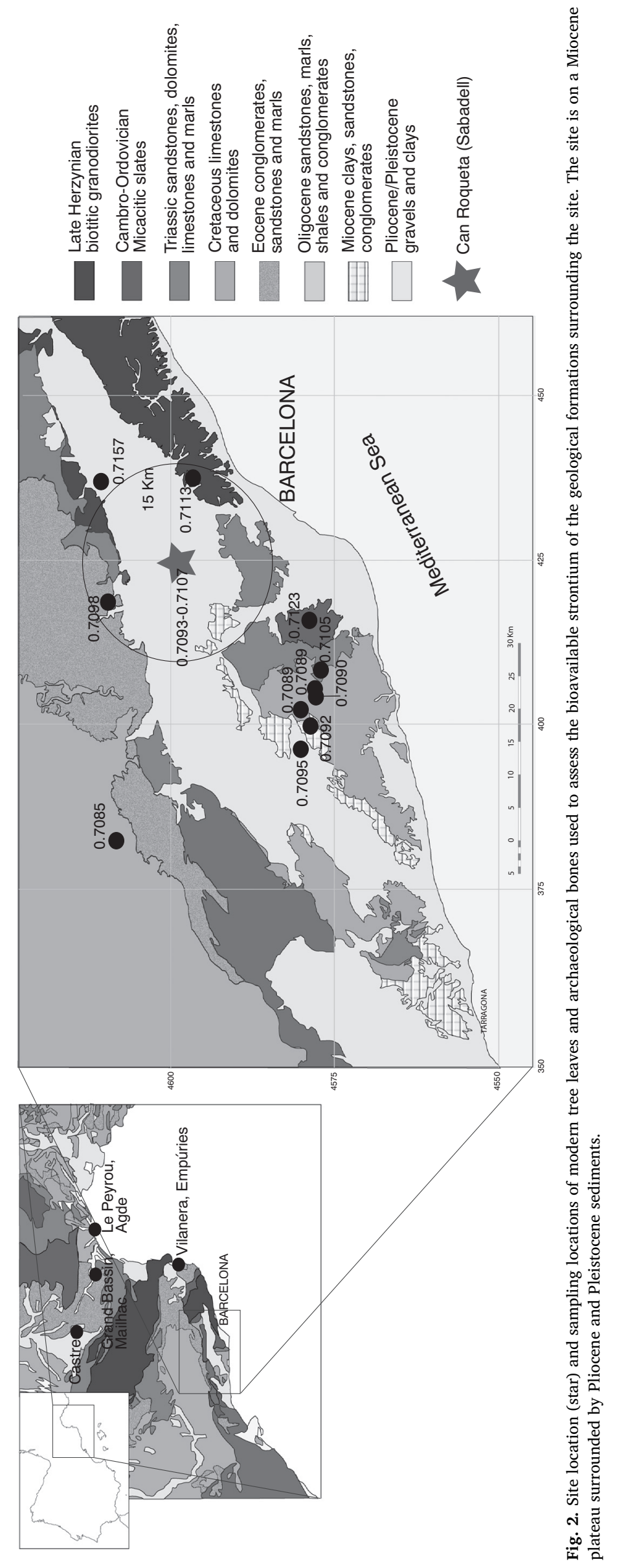




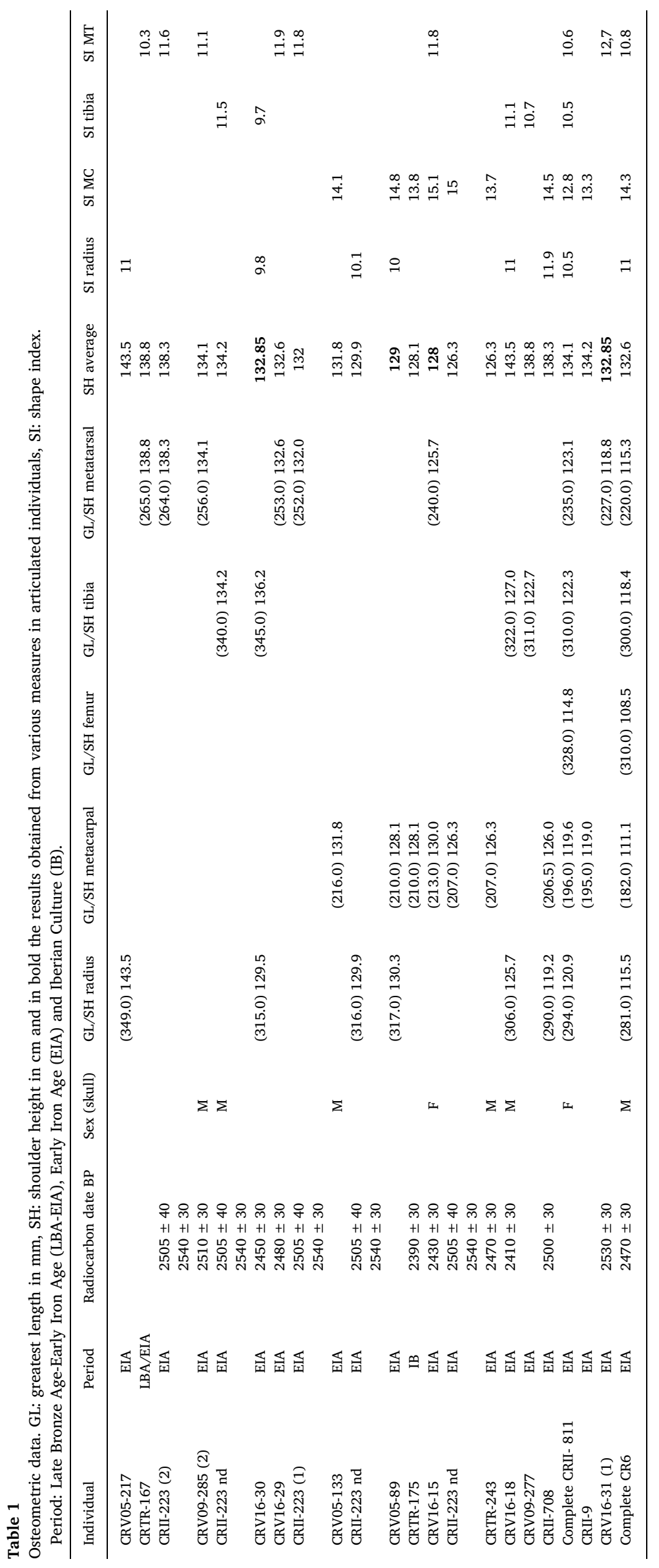


Table 2


mineralisation (Hoppe et al., 2004); Age D: age at death.

\begin{tabular}{|c|c|c|c|c|c|c|c|c|c|}
\hline Structure & Radiocarbon date BP & $95.45 \%$ probability & COD LAB & Sample & Type & $87 \mathrm{Sr} / 86 \mathrm{Sr}$ & 2std dev & Age M & Age D \\
\hline CR6 & $2470 \pm 30$ & 768 ВСЕ (92.4\%) 476 ВCE & Beta 449094 & Pm3 inf. & Enamel & 0.710253 & 0.000007 & $14-36 \mathrm{~m}$ & $10-13$ y (male) \\
\hline CRV09-294 & $2480 \pm 30$ & 774 ВСE (94.9\%) 482 ВCE & Beta 423328 & Pm3 inf. & Enamel & 0.712636 & 0.000007 & $14-36 \mathrm{~m}$ & $>5 y$ \\
\hline CRV09-285 (1) & $2510 \pm 30$ & $\begin{array}{l}790 \text { BCE }(27.7 \%) 701 \text { BCE } \\
696 \text { BCE }(67.7 \%) 540 \text { BCE }\end{array}$ & Beta 463865 & Pm3 sup. & Enamel & 0.711099 & 0.000008 & $14-36 \mathrm{~m}$ & 7-8 y (male) \\
\hline CRV05-79 (2) & $2590 \pm 30$ & 820 ВСЕ (92.7\%) 754 ВCE & Beta 423330 & Pm3 sup. & Enamel & 0.710341 & 0.000005 & $14-36 \mathrm{~m}$ & $10 \mathrm{y}$ (male) \\
\hline CRV05-103 & $2460 \pm 30$ & $\begin{array}{l}758 \text { BCE }(29.5 \%) 678 \text { BCE } \\
672 \text { BCE }(65.9 \%) 428 \text { BCE }\end{array}$ & Beta 423329 & I 2 inf. & Enamel & 0.711747 & 0.000005 & & $7 \mathrm{y}$ (male) \\
\hline CRII-223 (0) & $2540 \pm 30$ & $\begin{array}{l}799 \text { ВCE }(44.4 \%) 736 \text { BCE } \\
688 \text { BCE }(12.2 \%) 662 \text { BCE } \\
647 \text { BCE }(38.9 \%) 547 \text { BCE }\end{array}$ & Beta 423331 & I 2 inf. & Enamel & 0.710218 & 0.000007 & & $10 \mathrm{y}$ (male) \\
\hline CR6 & $2470 \pm 30$ & & Beta 449094 & Pm3 inf. & Dentine & 0.710049 & 0.000003 & & \\
\hline CRV09-294 & $2480 \pm 30$ & & Beta 423328 & Pm3 inf. & Dentine & 0.710735 & 0.000006 & & \\
\hline CRV09-285 (1) & $2510 \pm 30$ & & Beta 463865 & Pm3 sup. & Dentine & 0.710295 & 0.000005 & & \\
\hline Can Revella & 2016 & & & & Oak leaf & 0.709291 & 0.000007 & & \\
\hline Torre-romeu & 2016 & & & & Oak leaf & 0.710347 & 0.000003 & & \\
\hline
\end{tabular}

changes, thus preserving the isotopic signature of the area in which the animal was raised during tooth formation. Dentine is more susceptible to diagenetic alteration, and its strontium isotope values usually reflect those of the burial environment (Budd et al., 2000; Evans et al., 2007; Price et al., 2002). It can therefore be used as a baseline to determine the local strontium values of the archaeological site (e.g. Minniti et al., 2014; Viner et al., 2010).

Six equid teeth were sampled to assess place of rearing during the period of tooth formation (see Table 2). Only one case (CR6) coincides with the animals selected for the osteometric and pathological study (see Table 1) because in general the specimens studied did not have teeth available.

A transversal slice from the protoconid of each tooth was taken for strontium isotope analysis using a diamond cutter disc coupled to a dentist drill. Only fully formed teeth (i.e. in terms of wear and presenting largely closed roots) were chosen for analysis. Wherever possible, the sample was located just above the enamel root junction (ERJ) to facilitate data comparison. The results obtained thus reflect the final period of mineralisation of the sampled tooth (see Table 2 for details).

In addition, three dentine samples and two present-day evergreen oak leaves (Quercus cerrioides) taken from two different sectors of the site (namely, Can Revella and Torre Romeu) were analysed to obtain the strontium signature and the bioavailable strontium of different areas of the site.

The enamel samples were first cleaned mechanically using a rotating drill to remove the tartar, dentine and dirt, and then transferred to the Laboratoire de Géosciences-CNRS in Montpellier (France) to complete the process. This involved ultrasonic cleaning to remove any adhering material and immersion in $60^{\circ} \mathrm{C}$ ultrapure water for $1 \mathrm{~h}$ for further cleaning. After each cleaning phase, the sample was rinsed three times in MilliQ high purity de-ionised water. In a final cleaning step, the sample was immersed in an ultrasonic bath containing 5\% acetic acid for half an hour, and rinsed three or four times with pure water, to ensure that all potential remaining diagenetic effects had been removed. Once cleaned and dried in a laminar flow hood, the samples were weighed in pre-cleaned Teflon beakers. The samples were then dissolved in closed Teflon beakers with $1 \mathrm{cc}$ of tridistilled nitric acid $\left(8 \mathrm{M} \mathrm{HNO}_{3}\right)$ using sonication to help digestion during $15 \mathrm{~min}$ and subsequently put on a hotplate at $70{ }^{\circ} \mathrm{C}$ during $12 \mathrm{~h}$ followed evaporation to dryness. Samples were then diluted in nitric acid $2 \mathrm{M}$ and uploaded into Teflon columns filled with Eichrom Sr-Spec ion-exchange in order to isolate Sr using standard procedure (e.g. Pin et al., 1994). The strontium was purified following four steps of elution using various concentrations of nitric acid solutions. The solutions were then evaporated to dryness at $85^{\circ} \mathrm{C}$ before to be diluted with nitric acid $2 \%$ in order to be analysed using a Neptune + ThermoScientific Multi-
Collector Inductively-Coupled-Plasma Mass Spectrometer (MC-ICP-MS) from the AETE-ISO platform (OSU OREME) from the University of Montpellier. Total chemistry blanks were $<20 \mathrm{pg}$ and thus negligible for this study. The samples were alternatively run with international NBS 987 standards using a sample-standard-bracketing measurement protocol wherein standards were run every 3 unknowns. The ${ }^{88} \mathrm{Sr}$ beam intensity for all standards and samples ranges from $8 \mathrm{~V}$ to $15 \mathrm{~V}$. ${ }^{87} \mathrm{Sr} /{ }^{86} \mathrm{Sr}$ isotopic ratios were internally normalized from the instrumental bias using a value of 0.1194 for the ${ }^{86} \mathrm{Sr} /{ }^{88} \mathrm{Sr}$ ratio. Then the corrected ratios were normalized to the NBS 987 standards, which gave a mean value of 0.710245 with a reproducibility of $\pm 0.000004(2 \sigma$, $\mathrm{n}=8$ ) during the course of this study. Samples of present-day leaves were crushed using a pestle and mortar, and weighed into pre-cleaned pressure vessels in a clean laboratory environment. They were dissolved in Teflon distilled nitric acid ( $8 \mathrm{M} \mathrm{HNO}_{3}$ ) overnight at room temperature. Additional nitric acid and a trace of $\mathrm{H}_{2} \mathrm{O}_{2}$ were then added, before the samples were processed in a microwave oven at $175^{\circ} \mathrm{C}$ for $20 \mathrm{~min}$. The samples obtained were dried overnight on a hotplate prior to a secondary oxidation step involving the repetition of the entire process. To convert the samples to chloride, $6 \mathrm{M} \mathrm{HCl}$ was added, the sample was dried and a further $2 \mathrm{M} \mathrm{HNO}_{3}$ was added prior to strontium separation using the same chemical procedure as that previously described for enamel samples. The strontium isotope composition was determined by MC-ICP-MS using the same equipment as that used with the enamel samples.

\section{Results}

The zooarchaeological study of equid remains allowed us to identify 310 bones and a minimum number of 46 individuals, most presenting caballine characteristics. The remains are distributed around the whole of the archaeological site, but concentrate especially in the southern sector Can Revella (Fig. 1).

\subsection{Osteometric data}

Withers height estimations revealed a notable diversity in equid sizes (Table 1) among complete individuals or isolated bones in partial anatomical connection. Most presented a withers height between 125 and $135 \mathrm{~cm}$. Three specimens were between 110 and $122 \mathrm{~cm}$ and a further four specimens represented by isolated bones were around $140 \mathrm{~cm}$. Only a single individual (CRV05-217) was taller than $143.5 \mathrm{~cm}$ (Fig. 3).

The shape index, calculated on radii, metacarpals, tibias and metatarsals revealed the existence of two groups: a very slender group $(<13.5)$ and a slender group (13-14) (Fig. 3). But four individuals 


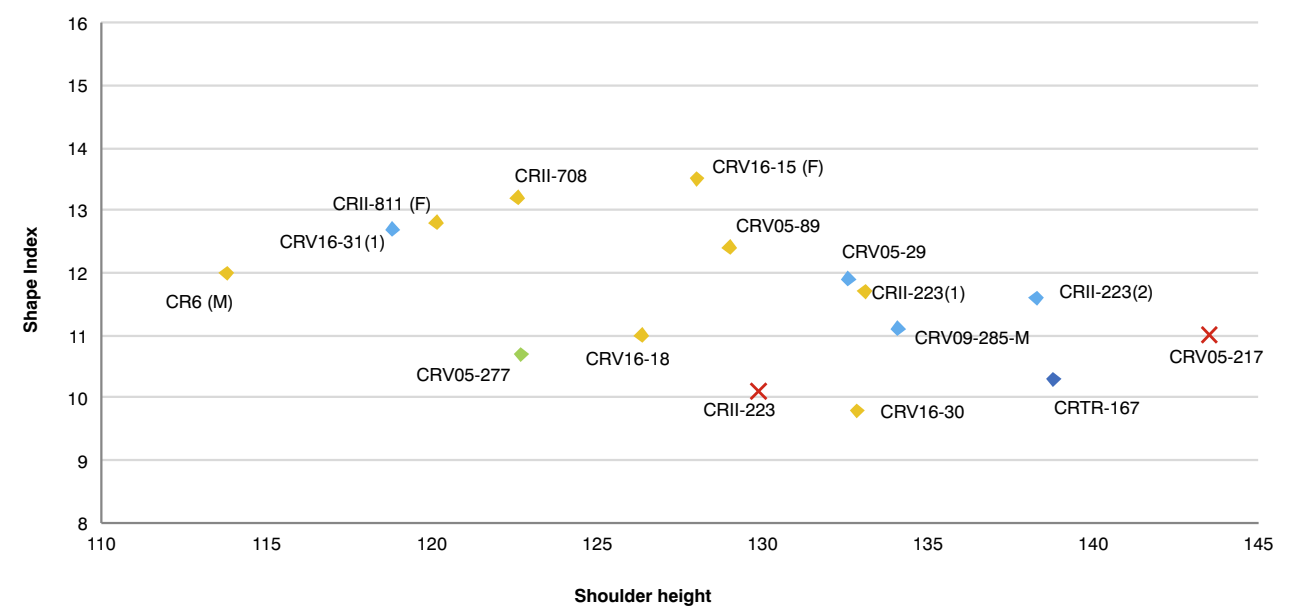

Fig. 3. Shoulder height ratio expressed as shape index: radii (red), metatarsal (blue), tibia (green). SH and SI average is calculated for individuals with more than two data (yellow). (For interpretation of the references to colour in this figure legend, the reader is referred to the web version of this article.)

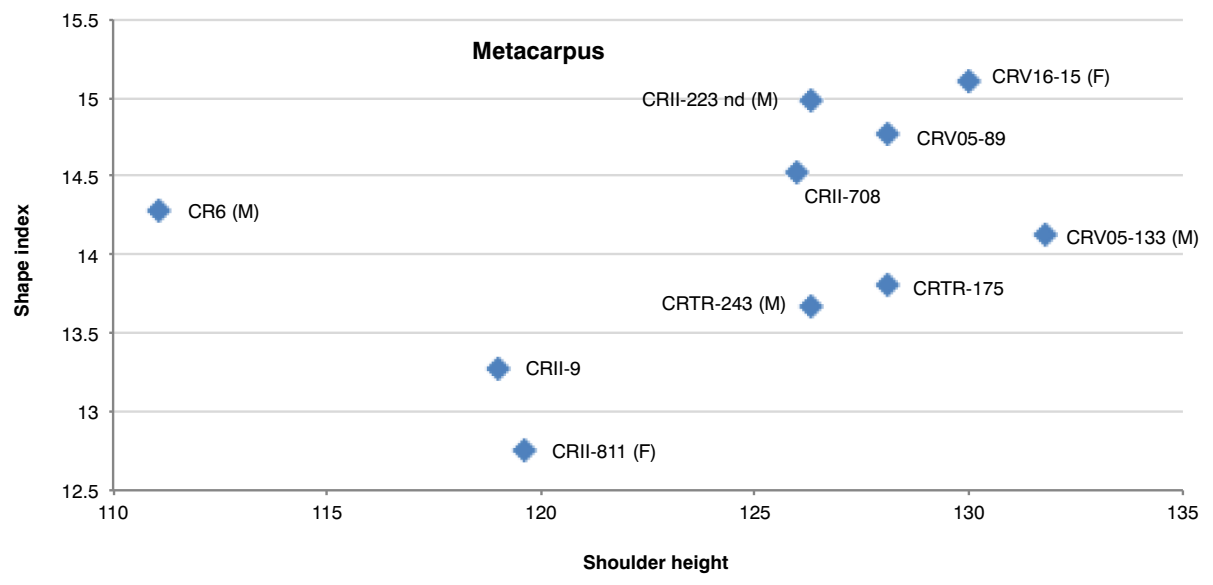

Fig. 4. Shoulder height ratio expressed as shape index $(S D \times 100 / G L)$ in metacarpal bone.

presented higher values in relation to their metacarpals (14.5-15, medium slender) (Fig. 4), in accordance with Brauner's metacarpal slenderness index. We recorded diversity of sizes - tall and less tall horses - in the very slender and slender groups. In general, for those individuals for both metacarpals and metatarsals were present, the index of robustness was higher for metacarpals than for metatarsals (Table 1). In individuals represented by all skeletal elements (e.g. CR6 and CRII-811), we found no correlation between the greatest length and breadth of the different bones, which seems to be indicative of allometric growth differences (Table 1). The variability observed in the withers heights and the robustness of the individuals might reflect specific incidents in the development of the animals, such as castration. In the metacarpals attributed by sex (Fig. 4), both males and females present the same range of variability, and it would seem that there is no sexual differentiation in terms of the morphology.

In general, the morphological characteristics presented by the metacarpus and metatarsi are horse-like. But the classification of one specimen (CRV05-89) is unclear as its metacarpus presents mule-like morphological traits (Fig. 5) (Johnstone, 2004). The correlation between GL and SD of the metacarpus places this individual among the tallest and most robust specimens, near to archaeological and modern mules (the offspring of a male donkey - jack - and a female horse - mare -) (Fig. 6). The main group is defined by the length $(>200 \mathrm{~cm})$ and midshaft width $(>28 \mathrm{~cm}$ ). In contrast, some individuals, most notably CRII-811 and CRII-9, occupy an intermediate position between the group of horses and donkeys in Eisenmann's dataset. Despite there having horse-like osteological characteristics, we cannot rule out a hybrid origin. The male CR6 presents values that correspond closely to those of the donkeys (Figs. 5, 6) but their skeleton presents morphological caballine characteristics (severe wear of its dentition impedes the analysis of discriminant parameters). These characteristics force us to exclude him from the group of donkeys and to include him in the smaller hybrids such as the hinnies, which is the offspring of a female donkey (jenny) and a male horse (stallion). This group also includes the specimens CRII-811 and CRII-9 (Figs. 5, 6).

The comparative morphometry of the metacarpus (Fig. 7) reinforces the hypothesis of the presence of two clearly differentiated groups of equids at Can Roqueta. Among the smallest, the complete specimens CR6 (male) and CRII-811 (female) and the articulated limb of CRII-9, present measurements more similar to those of the donkey, albeit with different metacarpal dimensions (Fig. 7). The remaining specimens are all larger and more robust.

\subsection{Mortality profiles and sex}

The age of death of 46 individuals in Early Iron Age are estimate. The mortality profiles define clearly a selection of adult animals between the ages of 5 and 10 years. Only one individual - Torre Romeu CRTR-179 - was aged below this. On the basis of their deciduous dentition their age is between one and two and a half years, and, as such, was still a juvenile (Fig. 8). Taphonomic explanations for missing young animals can be excluded, as new-borns or young animals from other species (e.g. dogs, piglets) are present at Can Roqueta site.

Among the adults, about $48 \%$ died when they were older than 


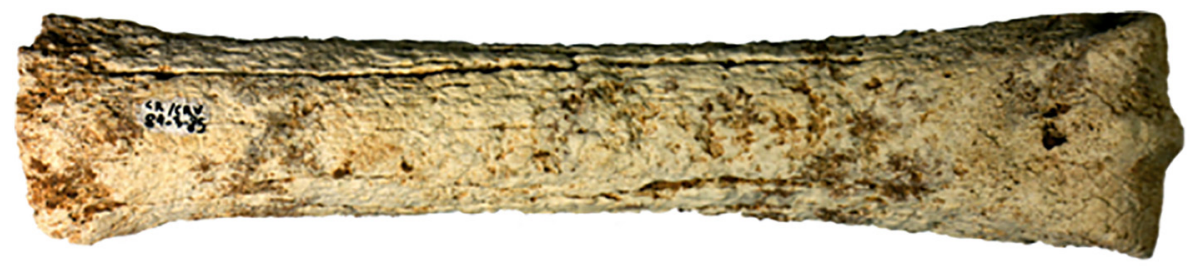

$10 \mathrm{~cm}$


Fig. 5. CRV05-89 metacarpal. Details of distal morphology (palmar view).

5 years. This means most of the equids found in Can Roqueta were old enough to have been tamed, saddled and mounted, and to have reached reproductive maturity and adult weight. As such they would have been used for several years before they died. In preserved skulls and mandibles male characteristics, that is, bulky canines are present (see Tables $1,2)$. All in all, our results point to a shortage of females, at least among the animals deposited as ABGs. The higher presence of males in the ABGs can attest from a selection of individuals for ritual or symbolic value.

\subsection{Pathologies}

Several horses present visible wear marks in the second premolars (PM2) of the mandible and maxilla, at the point where the bit impacts in the mouth. According to dental wear studies in archaeological horses the presence of such features is indicative of the use of metal bits (Anthony and Brown, 1989; Brown and Anthony, 1998; Bendrey, 2007a). Individuals CRV16-15, CRV16-18, CRV05-79 (2), CRV16-31 and CRTR-179 show tooth wear in the shape of a step (Fig. 9). The heavy wear shown by individual CRV05-79 (2) (Fig. 10) may be due to

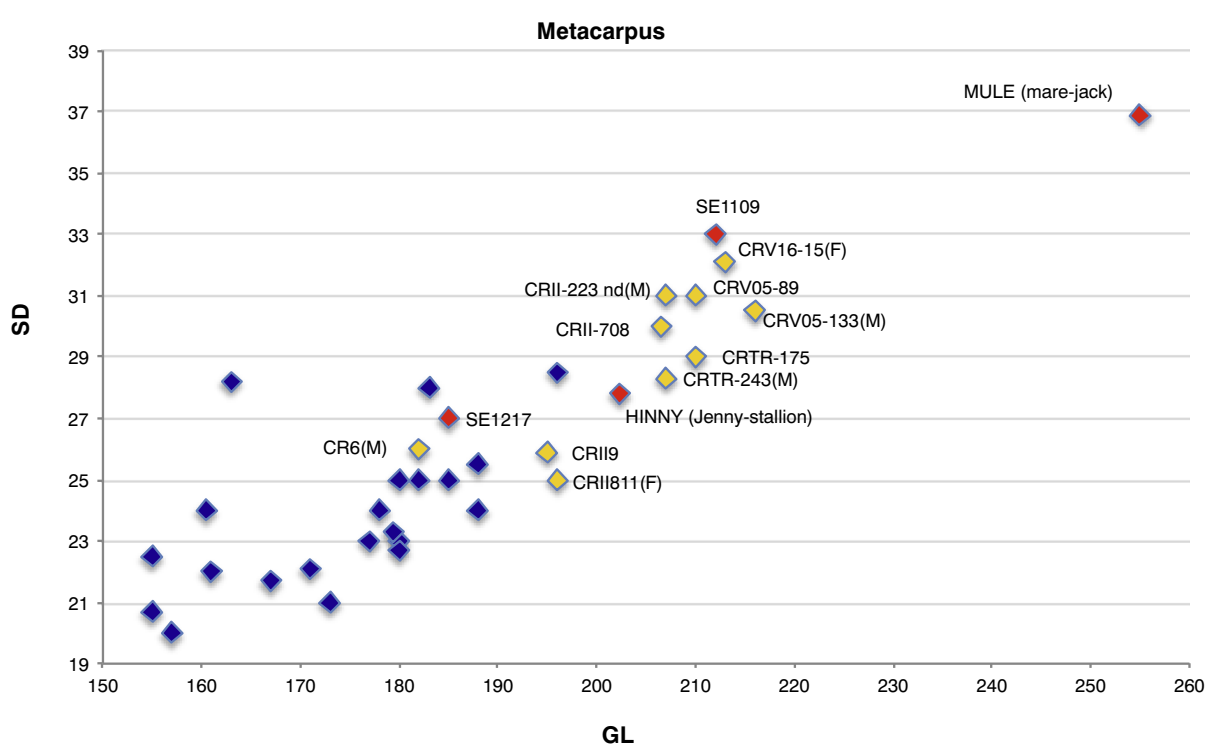

Fig. 6. Metacarpal measurements correlation: greatest length (GL) and midshaft width (SD). Can Roqueta equids (yellow); donkeys from Eisenmann's dataset (blue). Archaeological -Serrat dels Espinyers site- and modern hybrids (red) are from dataset of Albizuri et al. (2017). (For interpretation of the references to colour in this figure legend, the reader is referred to the web version of this article.) 

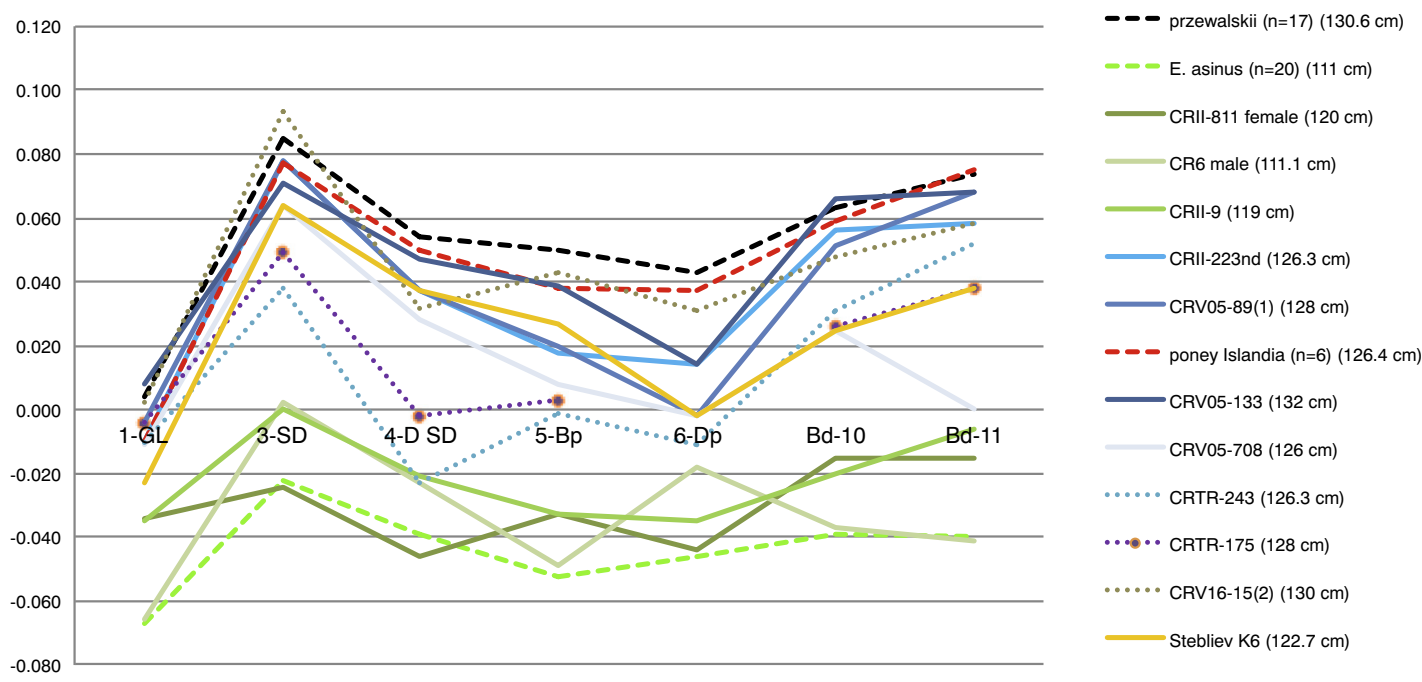

Fig. 7. Logarithmic differences of the metacarpal measurements in horses and asses (Onager - Equus Hemionus - is used as a standard. Shoulder height is estimated in $115.8 \mathrm{~cm}$ ). The shoulder heights for each specimen were estimated in the metacarpus. Data of Onager, donkeys - Equus asinus -, Przewalskii, Island pony and Steblev's horse K6 (Kiev, 5th century BCE) are extracted from Eisenmann's dataset.

GL: maximum length, SD: smallest midshaft width, D SD: thickness of the midshaft, Bp: maximum width of the proximal joint surface, Dp: maximum thickness of the proximal joint surface, Bd-10: maximum width of the surface distal joint on the trochlea, Bd-11: maximum width of the distal joint surface in the trochlea.

poorly fitting bit, with the horse developing the habit of biting down on the bit (Cook and Strasser, 2003). This type of wear has also been recorded in horses of the Early Iron Age Iberian Peninsula (Soto de Medinilla in Liesau, 1998) and at the Buhen site in Egypt, dated from 1675 BCE (Clutton-Brock, 1974). Furthermore, four iron snaffles were found inside the tombs at the necropolis of Can Piteu-Can Roqueta, dated from the Early Iron Age (Carlús et al., 2007; López-Cachero, 2014). The measurements of these snaffles correspond anatomically with the horse jaws documented at Can Roqueta (Albizuri, 2014).

A rubbing bit can damage the horse's soft tissue structures, resulting in mandibular periostosis on the surface of the diastema in the free space between the canines and the premolars (Bendrey, 2007a). Damage attributable to the bit includes the bone spurs observed in three Can Roqueta equids (complete mare CRII-811 - Fig. 11 - and individuals CR6 and CRII-223).

Osteophytes have been observed at the ends of the posterior or palmar face of some of the fore 1st phalanxes at the point of insertion of the flexor tendons. These pathological findings are related to trauma and other factors such as age (Bendrey, 2007b; Rooney, 1997; Thomas, 2017). The small lesions can also be attributed to stress of the tendons given the exertions associated with the traction of carts and/or ploughs (Fig. 12).

During load dragging, the horse's fore limbs are subjected to a greater force and pressure than the hind limbs. This was more so before the appearance of the plough head collar in the Middle Ages (Lignereux et al., 1998). However, the study of an isolated pathology can be misleading, since, for example, the exostoses may have an infectious or traumatic origin or may be associated with ageing. It is, therefore, important to have the complete skeletons from which a comprehensive study provides a differential diagnosis. Indeed, the complete mare of Can Roqueta (CRII-811) presents a set of pathologies that can be related to dragging (plough, chart, etc.) and carrying loads on the loins (Albizuri et al., 2010). The lesions observed include significant enthesophytes or bone neoformations caused by the age of the animal ( $>10$ years) or by the constant pressure of a strap on the right scapular girdle and an obvious neoformation on the margin of the glenoid cavity (right proximal humerus is broken and so possible alterations in this area are not observable). This neoformation invades the path of the circumflexa scapolae artery on the neck of the scapula, near the shoulder joint surface (Fig. 13A). These pathological changes might be related to continuous effort and oppression in the articulation area of the humerus and scapula where the clamping unit or strap would press. An example of similar pathologies was recorded on the scapulo-humeral joints of a 3rd century CE Roman horse, excavated in a pit of Bois Harlé (Oise) (Lepetz, 1990). These lesions were interpreted as resulting from the animal having been used for draught purposes, as they are characteristic and well documented in draught horses of the 19th and 20th centuries CE (Lepetz, 1990).

Individual CRII-811 also presents enthesophytes over the vertebral bodies and transverse process from the 11th thoracic to the 2nd lumbar vertebrae (Fig. 13B, C). In some cases, impingement of the supraspinous processes is observed with partial ankylosis of one process to the next

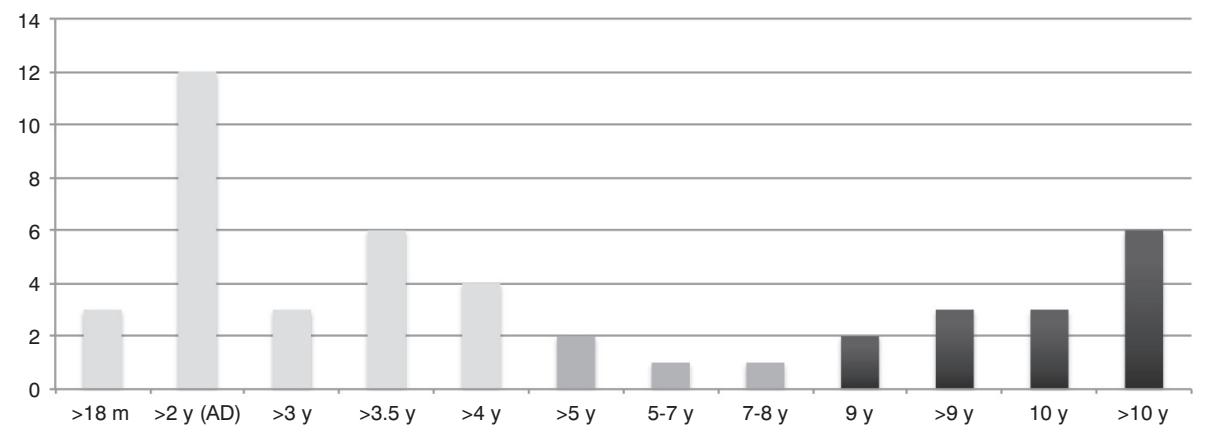

Fig. 8. Mortality profiles. 


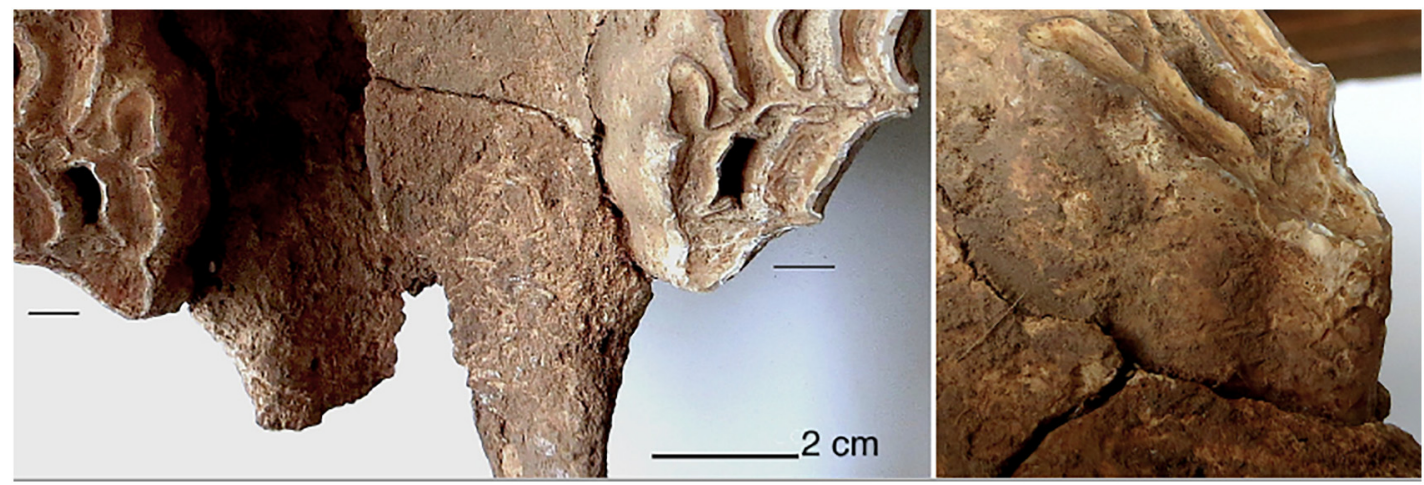

Fig. 9. CRV16-31: concave abrasion in anterior surface of both upper PM2. Occlusal view (left), labial surface view (right).

("kissing spines") (Albizuri et al., 2010). This pathology is related to the animal having been ridden bareback or with a soft saddle, according to the studies of Levine (Levine, 2005; Levine et al., 2000) on ScythoSiberian horses dated from the 5th to the 3rd centuries BCE. But the pathological incidence between the 11th thoracic and the 2nd lumbar also suggest that this animal had loaded weight in the posterior area of the back, on the loins. In summary, these pathological features on the spinal cord coincide with natural ageing processes and can be caused by


\section{$2 \mathrm{~cm}$}

Fig. 10. CRV05-79 (2): concave strong abrasion in anterior occlusal surface of lower PM2. Labial surface view (left), occlusal and anterior surface view (right). 


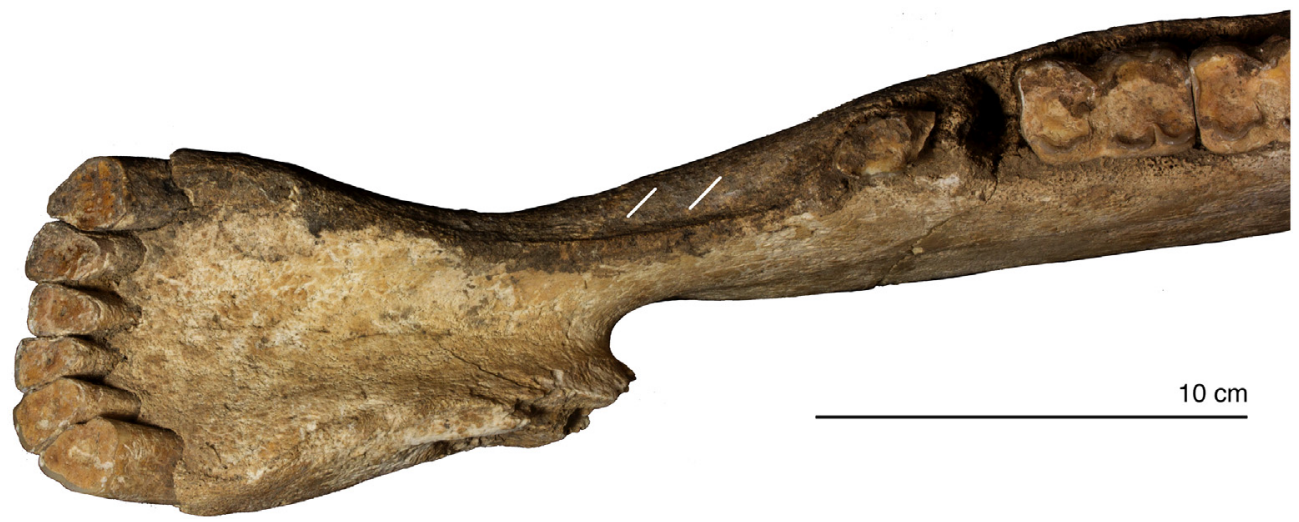

Fig. 11. CRII-811: diastema osseous ridge. Details of fracture on the distal half of the second premolars due to an abnormal occlusion (were produced shortly before the death of the animal as partial bone alveolar resorption can be observed).



Fig. 12. CRV05-133: Pathological changes on first anterior phalanx (palmar view).

congenital and hereditary factors, as well as intensive labour, such as riding and traction (Bartosiewicz and Bartosiewicz, 2002). Similarly, lumbar injuries could also be linked with load carrying. Horses with such pathology in the spinal column might have been ridden before skeletal growth was completed (Janeczek et al., 2012). This old female also presented bite damages on the mandibular diastema and may reflect that the animal was ridden.

\subsection{Geographic origin of equids at Can Roqueta}

Table 2 summarizes the strontium isotope results obtained on both the archaeological samples and the present-day leaves. The strontium isotope ratios of the local baseline samples (dentine and leaves) range between 0.7093 and 0.7107 . These values are in close agreement with those recorded in other samples of Pleistocene and Miocene sediments from other places (e.g. Evans et al., 2007; Scheeres et al., 2013; Valenzuela-Lamas et al., 2018; Voerkelius et al., 2010).

The archaeological enamel samples display a greater variability and range from 0.7103 to 0.7126 (Table 2 and Fig. 14). Three enamel samples - CR6, CRV09-285 (1) and CRII-223 (nd) - are consistent with the local strontium signature, whereas the other three (CRV09-294, CRV05-79 (2), CRV05-103) probably originate from another location. The only study mapping the bioavailable strontium in the central Catalan area (Valenzuela-Lamas et al., 2018) has registered values higher than 0.71101 on Middle Upper Palaeozoic sediments and Mesozoic metamorphic rocks, which occur about $15 \mathrm{~km}$ from the site, in both the Littoral mountain range and the pre-Littoral mountain range, which marks the limit of the Vallès-Penedès valley in which Can Roqueta lies.
Sediments of this kind are also present in other areas of Catalonia, including Cap de Creus and the Pyrenees (180 km range), and further afield in the mountains near Béziers (Montagne Noire), in France (Fig. 2). Studies conducted in other geographical areas of Western Europe have also reported ranges between 0.71101 and 0.71300 on Middle Upper Palaeozoic sediments and Mesozoic metamorphic rocks (e.g. Evans et al., 2007; Scheeres et al., 2013; Voerkelius et al., 2010; Waterman et al., 2014).

\section{Discussion}

The results of the zooarchaeological study - age at death, predominance of males based on the skulls and mandibles recovered and the pathologies registered - suggest the selection of adult male equids for the purposes of riding and work, at least as far as the remains deposited in the silos and other excavated structures indicate. The pathologies recorded on mandibles and maxilla suggests that the equids were bitted and, probably, ridden. In the case of the complete mare specimen, CRII-811, there is the highly suggestive physical evidence on its back of her having been used for dragging loads.

The variability in the shape index values and the withers heights may reflect sexual dimorphism and local/regional variation in morphotypes (the influence of wild equids cannot be fully excluded). But in some metacarpals of Can Roqueta (see Fig. 6) males and females present a similar range of variability. The variability may also reflect the presence of hybrids. In this sense, some individuals present mule morphological and morphometric traits (e.g. CRV05-89, Figs. 5 and 6) and others present morphometric features close to archaeological and modern hinnies (e.g. CR6, CRII9, CRII811, Fig. 6). Alternatively, the differences might be attributed to the effects of castration and to the age at which this was performed, since if bone growth was complete (over the age of 4), castration would not influence any increase in bone robustness. This fact is critical in work animals (Johnstone, 2004). Castration is widely documented in Greco-Latin writings, and was used for the more effective management of animals, since it reduces aggression. However, the effects of castration on mules have not been extensively studied, though it seems that in young castrated animals today their bones maintain their graceful characteristics (Chuang, 2016). A further factor to consider in the osteometric variability present is the influence of putting the animals to work, since this is likely to have affected the development of certain skeletal areas in the working horses (Hanot et al., 2018).

The range of withers heights of the Can Roqueta equids $(110-143.5 \mathrm{~cm})$ agrees with that reported for the Iron Age Celtic horses (c. $110 \mathrm{~cm}$ to $140 \mathrm{~cm}$ ) of the Iberian Peninsula and Western Europe (e.g. horses of Manching) (Altuna and Mariezkurrena, 2010; Liesau, 2005; Quesada, 2004). Specimens from France dated from the Bronze Age and the Early La Tène have an average withers height of around $130 \mathrm{~cm}$, 

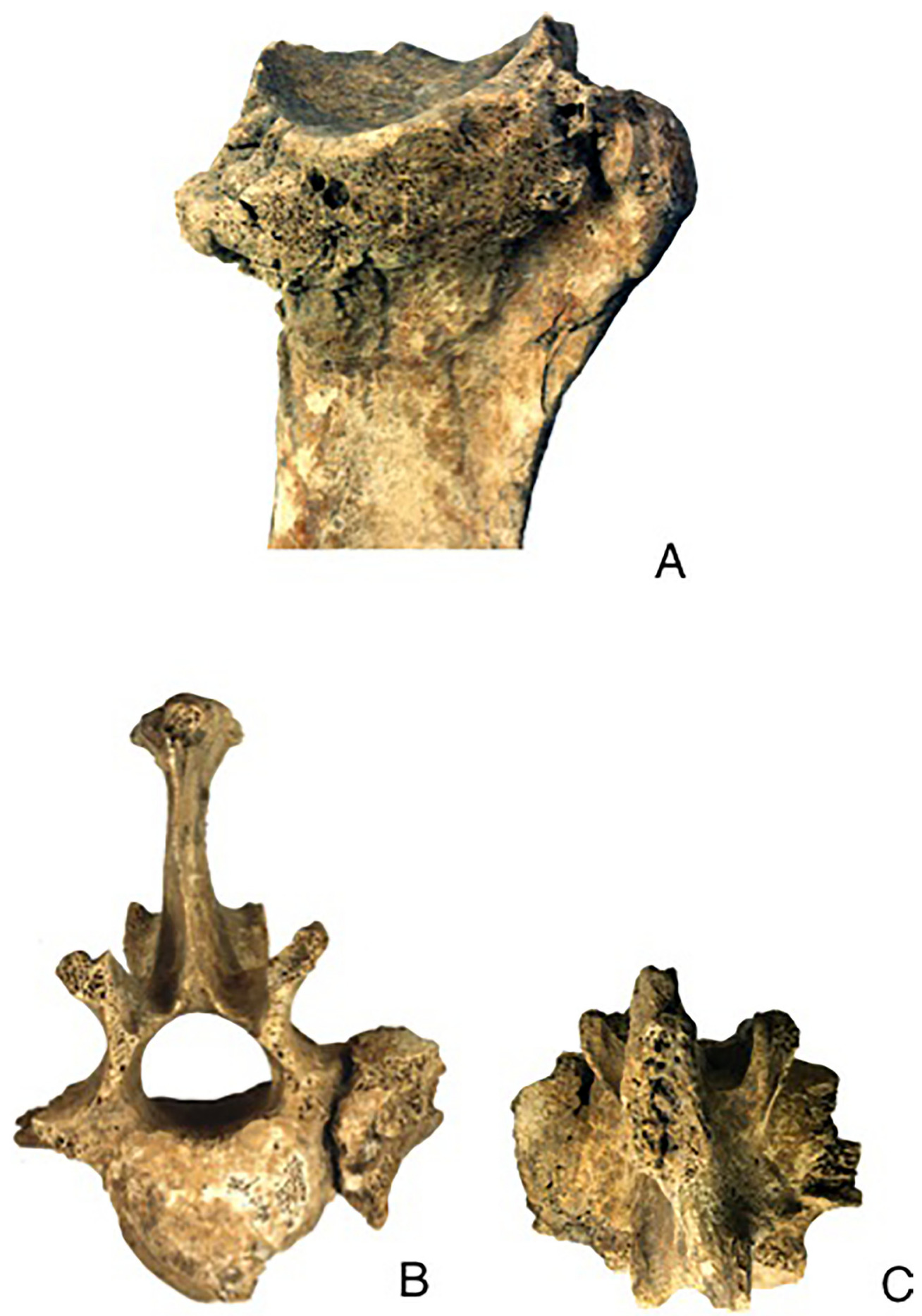

Fig. 13. CRII-811. (A) Pathological changes on the neck of the scapula, details (ventral view). (B) Bone neoformation in transverse process of first lumbar vertebrae (cranial view). (B) Details of pathological changes in spinous process (dorsal view).

and evidence of a wider range is only found from the 3rd c. BCE onwards (Arbogast et al., 2002). The variability in the withers heights at Can Roqueta may reflect the diversity of geographical origin of the equids, especially if we consider that Chalcolithic and Bronze Age equids in the Iberian Peninsula had withers heights around 130-145 cm (Legge, 1994; Liesau, 2005; Morales Muñiz, 1992). However, the presence of hybrids and donkeys among the remains identified as horses cannot be fully ruled out given the difficulties involved in equid species identification. Indeed, from the Early Iron Age onwards, "small equids" (hybrids?) appear in the archaeological record of the Iberian Peninsula, which coincides in time with the presence of Phoenician materials from the Mediterranean and with the introduction of the ass (Albizuri et al., 2016b). This is the case of three small size equids of Can Roqueta that could be assigned to the group of hinnies. In addition, these animals appear in a context where Phoenician materials have been recovered from silos and from two cremation tombs in the Can Piteu sector (Carlús et al., 2007).

The low incidence of females and juveniles seems to be inconsistent with on-site equid breeding, but it might equally reflect an archaeological bias due to the nature of the deposits. The characteristic of the remains reveals several types of intentional accumulations of equid bones (ABGs). Anatomical selection includes bone segments in 


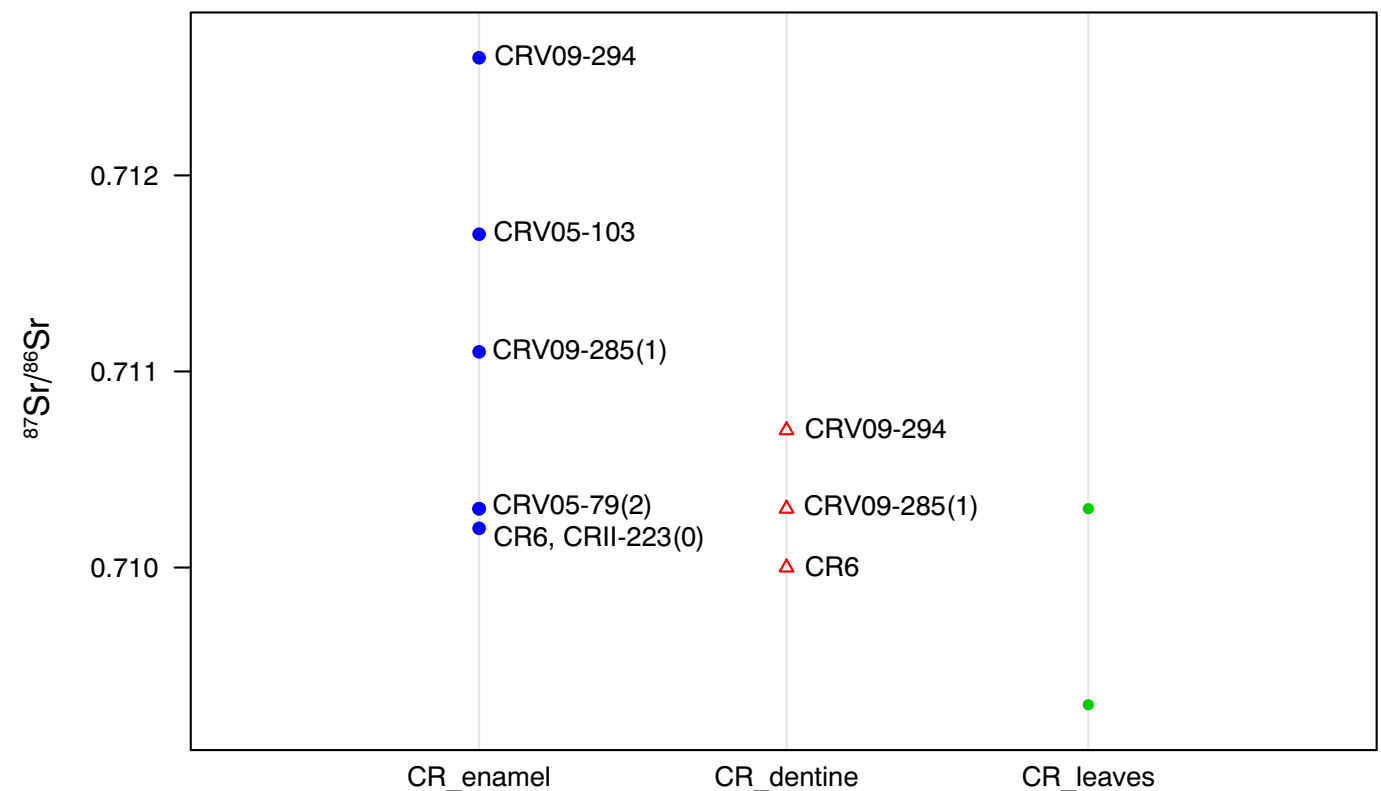

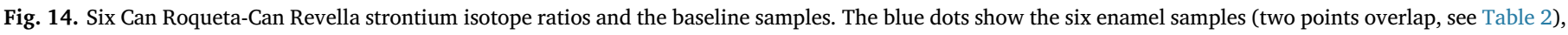


the references to colour in this figure legend, the reader is referred to the web version of this article.)

anatomical connection, isolated bones, and two complete skeletons. In the same way higher presence of males in the ABGs can be evidence a selection of individuals for ritual or symbolic purposes. In this case, the possibility that the individuals do not reflect the real composition and management of domestic equids at the site cannot be fully excluded. In any case, the individuals that we could gender correspond to six adult males and two adult females, but not to any juveniles. This does not coincide with what we would expect from a typical stud farm, even if the males had been castrated. In the Iberian Peninsula at present, a proportion of one stallion for every 5 to 10 mares (without counting the offspring) is the norm in semi-feral herds (Spanish Ministry of Agriculture, 2003).

The results of the strontium isotope analysis suggest the presence of two distinct geographical origins for the six individuals sampled, although seasonal movements cannot be ruled out here. Three of the individuals present strontium signatures that are compatible with the geological layer on which the site is located - 0.7102-0.7103: individuals CR6, CRV09-285 (1) and CRII-223 (nd). However, the wide extension of Cenozoic sediments in the Iberian Peninsula and neighbouring areas does not allow us to determine, on the sole basis of the strontium values, whether these three samples were raised on the site or somewhere else with similar strontium ratios. Conversely, three individuals (CRV09-294, CRV05-79 (2) and CRV05-103) present higher strontium values (0.7111-0.7126). Based on the local bioavailable strontium sampling as well as on other values drawn from the literature (Scheeres et al., 2013; Valenzuela-Lamas et al., 2018; Voerkelius et al., 2010), these strontium ratios correspond with those detected in relation to Triassic sediments. Within a $200-\mathrm{km}$ radius of the site, Triassic sediments are present in the nearby Collserola mountain as well as in the Montseny, Albera-Serra de Rodes, and the Montagne Noire in France (Fig. 2).

The teeth were all sampled close to the enamel-root junction, so the strontium values reflect the latest period of enamel mineralisation (at around age 3 , see Table 2). This means that three of the animals would have been grazing somewhere with Triassic sediments when they were about 3 years old. As stated above, seasonal movement between different geological areas during the period of enamel mineralisation cannot be fully ruled out, as we only have one sample per tooth. However, a more plausible explanation is that (at least some of) the equids of Can Roqueta were acquired as a final product, i.e. older than 3 years old and when they were old enough to be trained for riding and work.

The archaeological evidence suggests that the territory comprising the whole of the Vallés area as well as the immediate coastal zone were integrated within the same cultural entity (López-Cachero, 2014; López Cachero and Rovira, 2012). These communities would have exploited the rich variety of resources in the surrounding mountains, suggesting that the equids may have originated from the local area and its surroundings. However, other more distant origins (e.g. the Pyrenees or the Béziers area) cannot be ruled out. Contact with the Pyrenees is not well documented, there being evidence only of temporary cave occupations and the presence of some cremation necropolises. Within the Pyrenees, the most likely areas of origin would be the plain of La Cerdanya or the mountainous area between the Albera range and the Serra de Rodes (Fig. 2). The latter, moreover, lies very close to the Empordà, which was an active trading area during Protohistory a time when the Greek colony of Emporion - and earlier settlements on this site - was one of the main trading points during the Iron Age in this area (Fig. 2). The similarity of the metallic objects recovered at the necropolis of Vilanera (Empordà) and those of the necropolis of Can PiteuCan Roqueta (Fig. 1) suggest the existence of trade - or at least of some influence - between these two areas. The specific elements that support this claim are the similarities between the iron knives and certain types of fibulae found at both sites, in particular those with a serpentiform (López Cachero and Rovira, 2012; Rovira and López-Cachero, 2016). Some morphotypes of metal objects (i.e. knives, horse bits, fibulas and needles) similar to those found in Can Piteu-Can Roqueta have also been recovered in some cremation necropolises in southeastern France, especially in those lying close to the Montagne Noire. This is the specific case of the necropolis of Grand Bassin in Mailhac, and of the three necropolises of Castres and Le Peyrou in Agde (Rovira and LópezCachero, 2016). Additionally, the lead isotope analyses performed on some bronze objects from the necropolis of Can Piteu-Can Roqueta (i.e. a Mialhacian arrowhead, and a double-spring fibula) (Rovira et al., 2008; Rovira and López-Cachero, 2016) show the probable use of copper ores from the area of Les Cévennes - located in the area adjacent to the Montagne Noire -.

Consequently, the ensemble of information - archaeology, 
zooarchaeology, Sr geochemical data - points to the complex management of Can Roqueta's equids population. The combination of isotope data from six individuals and the archaeological finds suggests that (at least) some of the equids from Can Roqueta could have been introduced to the site having already been tamed and trained, perhaps from the Empordà or south-eastern France. Local breeding in neighbouring mountain areas cannot completely be ruled out, but the lack of juvenile and foetal remains and the low percentage of females greatly weaken this hypothesis. Indeed, there is evidence of the exchange of horses in Europe during the Iron Age (Bendrey et al., 2009; Gerling, 2015; Nuviala et al., 2014). Regardless of the role or roles attributed to horses in Early Iron Age societies in Iberia and Europe, equid deposits documented at the site and snaffle bits documented in the necropolis of Can Piteu-Can Roqueta suggest the emergence of people of differentiated status associated with the use of horses (Albizuri et al., 2016a). From the late 7th c. BCE, and especially during the 6th c. BCE, the progressive appearance of weapons in the necropolises of the northeastern Iberian Peninsula and southern France suggests that the material related to equid riding, as well as the greater presence of horses in the faunal record, reflects the consolidation of a warrior elite in these societies (Gailledrat, 2015; Graells, 2013; López Cachero and Rovira, 2012). Further studies will be able to expand the number of samples so that we can address the question of the provisioning and mobility of horses in greater depth. Moreover, studies examining the diet together with DNA analyses are currently underway.

\section{Conclusion}

The absence of foetal and juvenile remains together with the low percentage of females suggest that Can Roqueta was not a centre for equid breeding despite the important volume of equid bone remains recovered. The predominance of adults with caballine characteristics and the pathologies related to work and riding indicate a probable supply of horses (and probably donkeys) from other places. The strontium results may support this hypothesis since some of the six equids analysed could have been brought to the site once tamed and trained (i.e. after they were 3 years old). On the other hand, commercial relations with the area of the Pyrenees and Phoenician materials in Can Roqueta can explain the supply of equids. Previous studies on the metallic items recovered at the site (i.e. iron knives and fibulae; López Cachero and Rovira, 2012) attested the existence of contacts between the Vallès area, the Empordà, and southeastern France (Béziers area). Indeed, an analysis of the lead isotopes of these items from Can Roqueta confirmed that copper ores from South-eastern France were used in their fabrication. Likewise, animals may also have originated from the Empordà or from South-eastern France, although local breeding in the neighbouring hinterland cannot be completely ruled out.

These results considerably broaden our knowledge about the breeding of horses and other equids in the Iberian Peninsula, especially for the Early Iron Age where the remains of equids are very scarce. In this first work we prioritized the specimens that provided more information about the age, the morphometric characteristics and the pathologies. But within the available sample there are more cases (teeth) for the analysis of strontium that will be part of a second work that broadens the problematic about the breeding and exchange of these animals.

\section{Declaration of Competing Interest}

None.

\section{Acknowledgments}

This paper was written as part of the research undertaken by the consolidated research group SGR2017-00011 Seminari d'Estudis $i$ Recerques Prehistòriques (SERP), and was funded by Ministerio de
Economía y Competitividad of Spain, within the projects HAR201348010-P and HAR2017-87695-P. We are grateful whith the collaboration of Ramón Alvárez Arza of the University of Barcelona, Department of History and Archeology (SERP) for his photographic work.

The authors thank the two anonymous reviewers for their valuable insights to improve the work.

\section{References}

Albizuri, S., 2014. La visibilitat del cavall en el registre arqueològic del NE peninsular durant el final de l'edat del bronze i la primera edat del ferro. L'exemple de Can Roqueta (Sabadell, Vallès Occidental), La transició bronze final - primera edat del ferro en els Pirineus i territoris veïns, XV Colloqui Internacional de Puigcerdà, Puigcerdà, 2011. pp. 579-593.

Albizuri, S., 2018. Noves dades sobre la ramaderia especialitzada en el treball i transport a les societats camperoles del bronze final i la primera edat del ferro en les depressions de l'Empordà i la Selva. Cypsela 21, 97-118.

Albizuri, S., Nadal, J., 1990. Estudi de l'èquid aparegut en relació amb l'Estructura E10 de l'Hort d'en Grimau. In: Mestres, J., Sanmartí, J., Santacana, J. (Eds.), Estructures de la Primera Edat del Ferro de l'Hort d'en Grimau (Castellví de la Marca, Alt Penedès). Olerdulae XV, pp. 112-117.

Albizuri, S., Fernández, M., Lloveras, Ll, 2010. Using palaeopathological evidence to assess the economic importance of horses in the North East part of the Iberian Peninsula during the early Iron Age, Animal Diseases in Past Human Societies. In: Proceedings of the Fourth ICAZ Animal Palaeopathology Working Group Conference, April 2010, Katerini, Greece.

Albizuri, S., Alonso, N., López Cachero, F.J., 2011. Economia i canvi social a Catalunya durant l'edat del bronze i la primer edad del ferro. In: Valenzuela-Lamas, S., Padrós, N., Belarte, M.C., Sanmartí, J. (Eds.), Economia agropecuària i canvi social a partir de les restes bioarqueològiques. El primer millenni aC a la Mediterrània occidental. vol. 12. Arqueo Mediterrània, pp. 11-36.

Albizuri, S., Oliva, M., Majó, T., 2016a. Una inhumación del Primer Milenio BC con restos óseos de caballo (Can Roqueta-Can Revella, Cataluña). In: O Cavalo e o Touro na Préhistória e na História, Actas del I Congresso Internacional Equuspolis, GolegãChamusca 2013. Centro Português de Geo-História e Pré-História (CPGP), Portugal, pp. 107-116.

Albizuri, S., Font, L., Nadal, J., 2016b. Équidos de la primera Edad del Hierro: el impacto colonial en la zona meridional de Catalunya. In: O Cavalo e o Touro na Pré-história e na História, Actas del I Congresso Internacional Equuspolis, Golegã-Chamusca 2013. Centro Português de Geo-História e Pré-História (CPGP), Portugal, pp. 97-106.

Albizuri, S., Nadal, J., Belmonte, C., Garcés, I., 2017. Los efectos de la romanización en la gestión ganadera: la cabaña equina de Serrat dels Espinyers (Lérida) como ejemplo de la producción mular en la Península Ibérica. I Reunión Científica: la Romanización en la Península Ibérica. Una visión desde la Arqueozoologia, septiembre 2013. Archaeofauna 24, 115-126.

Alcalde, G., Molist, M., Saña, M., Toledo, A., 1997. Procés d'ocupació de la Bauma del Serrat del Pont (la Garrotxa) entre 2900 i 1450 aC. In: Publicacions Eventuals d'Arqueologia de la Garrotxa 2. Museu Comarcal de la Garrotxa, Olot.

Alonso, N., Bergadà, M., Gené, M., Gómez, X., Juan, J., Junyent, E., Lafuente, A., López, J.B., Mazo, C., Moya, A., Nadal, J., Piqué, R., Riera, S., Tartera, E., 2002. L'assentament protohistòric, medieval i d'època moderna de El Vilot de Montagut (Alcarràs, Lleida). In: Recuperant el passat a la línia del tren d'alta velocitat. Pagès Ed., Lleida, pp. 211-216.

Altuna, J., Mariezkurrena, K., 2010. El caballo al final de la última glaciación y en el periodo postglacial del País Vasco, Euskal pottoka, EPOFE, Azpeitia, Gipuzkoa, pp. $1-38$.

Anthony, D.W., Brown, D.R., 1989. Looking a gift horse in the mouth: identification of the earliest bitted equids and the microscopic analysis of bit wear. In: Crabtree, P.J., Campana, D., Ryan, K. (Eds.), Early Animal Domestication and its Cultural Context. MASCA Research Papers in Science and Archaeology 6, Special Supplement. MASCA, The University Museum, Philadelphia, pp. 98-116.

Arbogast, R.M., Clavel, B., Lepetz, S., Méniel, P., Yvinec, J.H., 2002. Archéologie du cheval, Errance. París.

Balasse, M., Ambrose, S.H., Smith, A.B., Price, T.D., 2002. The seasonal mobility model for prehistoric herders in the south-western Cape of South Africa assessed by isotopic analysis of sheep tooth enamel. J. Archaeol. Sci. 29 (9), 917-932.

Barone, R., 1976. Anatomie comparée des mammifères domestiques, Tome 1. In: Ostéologie, deuxième édition. Vigot Frères, Paris.

Bartosiewicz, L., Bartosiewicz, G., 2002. Bamboo spine in a migration period horse from Hungary. J. Archaeol. Sci. 29, 811-830.

Bendrey, R., 2007a. New methods for the identification of evidence for bitting on horse remains from archaeological sites. J. Archaeol. Sci. 34, 1036-1050.

Bendrey, R., 2007b. Work- and age-related changes in an Iron Age horse skeleton from Danebury hillfort, Hampshire. Archaeofauna 16, 73-84.

Bendrey, R., 2010. The horse. In: O'Connor, T., Sykes, N. (Eds.), Extinctions and Invasions. A social history of British fauna. WINDgather Press, Oxford, pp. 10-16.

Bendrey, R., Hayes, T.E., Palmer, M.R., 2009. Patterns of Iron Age horse supply: an analysis of stronium isotope ratios in teeth. Archaeometry 51, 140-150.

Bendrey, R., Lepetz, S., Zazzo, A., Balasse, M., Turbat, T., Giscard, P.H., Vella, D., Zaitseva, G.I., Chugunov, K.V., Ughetto, J., Debue, K., Vigne, J.D., 2017. Nomads, horses and mobility: an assessment of geographic origins of Iron Age horses found at Tsengel Khairkhan and Baga Turgen Gol (Mongolian Altai) based on oxygen isotope compositions of tooth enamel, in: Mashkour, M., Beech, M. (Eds.), Archaeozoology of 
the Near East 9 In honour of Hans-Peter Uerpmann and François Poplin. Proceedings of the 9th ASWA Conference, International Council of Archaeozoology (ICAZ), Al Ain. Oxbow Books, Oxford, Philadelphia, pp. 262-272.

Bentley, R.A., 2006. Strontium isotopes from the earth to the archaeological skeleton: a review. J. Archaeol. Method Theory 13, 136-187.

Beylier, A., 2012. L'armement et le guerrier en Méditerranée nord-occidentale au premier âge du fer, Publications de l'UMR 5140 du CNRS, Monographies d'archéologie méditerranéenne, Hors-série, 31. Lattes, France.

Brown, D., Anthony, D., 1998. Bit wear, horseback riding and the Botai site in Kazakstan. J. Archaeol. Sci. 25, 331-347.

Budd, P., Montgomery, J., Evans, J., Barreiro, B., 2000. Human tooth enamel as a record of the comparative lead exposure of prehistoric and modern people. Sci. Total Environ. 263 (1-3), 1-10.

Carlús, X., López Cachero, J., Oliva, M., Palomo, A., Rodriguez, A., Terrats, N., Lara, C., Villena, N. (coord.), 2007. Cabanes, sitges i tombes. El paratge de Can Roqueta (Sabadell, Vallès Occidental) del 1300 al 500 ANE. Quaderns d'Arqueologia 4, Museu d'Història de Sabadell Sabadell.

Chuang, R., 2016. The Acquisition of Domestic Equids in Roman Britain. The Identification of Domestic Equids and Case Study With Isotopic Analyses. Thesis for $\mathrm{PhD}$. Department of Archaeology, University of Southampton.

Clutton-Brock, J., 1974. The Buhen horse. J. Archaeol. Sci. 1, 89-100.

Comar, C.L., Russell, R.S., Wasserman, R.H., 1957. Strontium-calcium movement from soil to man. Science 126 (3272), 485-492.

Cook, W.R., Strasser, H., 2003. Metal in the Mouth: The Abusive Effects of Bitted Bridles. Sabine Kells, Qualicum Beach, BC Canada.

Davis, S.J., 1980. Late Pleistocene and Holocene equid remains from Israel. Zool. J. Linnean Soc. 70, 289-312.

Dedet, B., Marchand, G., 2016. Héros, caciques et paysans armés en Languedoc et en Provence du VIIIe au IIe siècles avant J.C. In: Belarte, M.C., Garcia, D., Sanmartí, J. (Eds.), Les estructures socials protohistòriques a la Gàllia i Ibèria. Homenatge a Aurora Martín i Enriqueta Pons, VII Reunió Internacional d'Arqueologia de Calafell, 7 marzo 2013, Calafell, pp. 67-85.

Eisenmann, V., 1979. Les metápodes d'Equus sensu lato (Mammalia, Périssodactyla). Geobios 12 (6), 363-886.

Eisenmann, V., 1980. Les chevaux (Equus sensu lato) fossiles et actuels: crânes et dents jugales supérieures, Cahiers de Paléontologie. CNRS, Paris.

Eisenmann, V., 1981. Etude des dents jugales inférieures des Equus actuels et fossiles. Palaeovertebrata 10 (3-4), 127-230.

Eisenmann, V., 1984. Adaptations esquelettiques chez des Equus sauvages actuels et fossiles. 10e journée d'étude, C.E.R.E.O.P.A. Institut National Agronomique, Paris, pp. $27-37$.

Eisenmann, V., 2009. Estimation des hauteurs au garrot. http://www.veraeisenmann. com/estimations-des-hauteurs-au-garrot.

Eisenmann, V., Beckouche, S., 1986. Identification and discrimination of metapodials from Pleistocene and modern Equus, wild and domestic. In: Meadow, R.H., Uerpmann, H.P. (Eds.), Equids in the Ancient World. Ludwig Reichert Verlag, Weisbaden, pp. 117-163.

Evans, J.A., Tatham, S., Chenery, S.R., Chenery, C.A., 2007. Anglo-Saxon animal husbandry techniques revealed though isotope and chemical variations in cattle teeth. Appl. Geochem. 22, 1994-2005.

Faure, G., Mensing, T.M., 2005. Isotopes: Principles and Applications. John Wiley Sons Inc.

Gailledrat, E., 2015. Tierra, fuego y agua: poder y sociedad entre el Ródano y los Pirineos durante la primera Edad del Hierro. In: Belarte, M.C., Garcia, D., Sanmartí, J. (Eds.), Les estructures socials protohistòriques a la Gàllia i a Ibèria. vol. 14. pp. 97-118 Arqueo Mediterrània.

Gerling, C., 2015. Prehistoric Mobility and Diet in the West Eurasian Steppes 3500 to. An isotopic approach. Series Topoi-Berlin Studies of the Ancient World, Topoi-Berliner Studien der Alten Welt, BC, pp. 300.

Gómez, X., 2003. Fetos de équido en Els Vilars (Arbeca, Lleida): un nuevo tipo de deposición en el hábitat durante la primera Edad del Hierro en Cataluña. In: Quesada, F., Zamora, M. (Eds.), El caballo en la antigua Iberia. Estudio sobre los équidos en la Edad del Hierro. Real Academia de la Historia, Colección B. Archaeologica Hispana, pp. 209-215.

Graells, R., 2013. De Italia al Bajo Aragón: la dinámica de intercambios indígena entre el s. VII y VI a. C., in: Colin, A., Verdin, F. (Dir.), Mobilité des hommes, diffusion des idées, circulation des biens dans l'espace européen à l'àge du Fer. Actes du XXVe Colloque de l'AFEAF (Bordeaux, 2-5 juin 2011), supplément 30 d'Aquitania, Bordeaux, pp. 727-736.

Grant, A., 1984. Animal husbandry. In: Cunliffe, B. (Ed.), Danebury: An Iron Age Hillfort in Hampshire. Council for British Archaeology, London, pp. 496-548.

Gruat, Ph., Garcia, D., 2016. Stèles et sculptures de la Celtique méditerranéenne du premier âge du fer (VIIIe-Ve s. av. J.-C.). In: Gruat, Ph., Garcia, D., Aurélien, P. (Eds.), Guerriers celtes du midi. Stèles et sculptures du premier âge du fer. Catalogue de l'exposition du Musée Fenaille, Rodez, pp. 11-35.

Guadelli, J.L., 1998. Détermination de l'âge des chevaux fossiles et établissement des classes d'âge/Age determination of fossil horses and the establishment of age classes. Paléo 10 (1), 87-93.

Hanot, P., Herrel, A., Guintard, C., Cornette, R., 2018. The impact of artificial selection on morphological integration in the appendicular skeleton of domestic horses. J. Anat. 232, 657-673.

Harcourt, R., 1979. The animal bones. In: Wainwright, G. (Ed.), Gussage All Saints: An Iron Age Settlement in Dorset. Archaeological Reports, vol. 10. Department of the Environment, Her Majesty's Stationery Office, London, pp. 150-160.

Hoppe, K.A., Amundson, R., Vavra, M., McClaran, M., Anderson, D.L., 2004. Isotopic analysis of tooth enamel carbonate from modern North American feral horses: implications for paleoenvironmental reconstructions. Palaeogeogr. Palaeoclimatol. Palaeoecol. 203, 299-311.

Janeczek, M., Chrószcz, A., Onar, V., Henklewski, R., Pikalski, J., Duma, P., Czerski, A., Calkosinski, I., 2012. Anatomical and biomechanical aspects of the horse spine: the interpretation of vertebral fusion in a medieval horse from Wroclaw (Poland). International Journal Osteoarchaeology. https://doi.org/10.1002/oa.2248.

Johnstone, C., 2004. A Biometric Study of Equids in the Roman World. Thesis for PhD. University of York.

Kmetová, P., 2017. Contacts between the Late Hallstatt groups of the Pannonian Basin, the south-east Alpine Hallstatt region and Veneti from the perspective of horse burials. In: Trefný, M., Jennings, B. (Eds.), Inter-regional Contacts During the First Millenium B.C. in Europe. Proceedings From the Session Organized During the 19th Meeting of European Association of Archaeologists (Pilsen, 2013), Hradec Králové, pp. 92-117.

Legge, Anthony J., 1994. Animals remains and their interpretation, in: Harrison, R., Moreno, G., Legge, A. (Eds.), Moncín: un poblado de la Edad del Bronce (Borja, Zaragoza). Colección Arqueología, 16, Zaragoza, pp. 453-482.

Lepetz, S., 1990. Le cheval gallo-romain du puits 116 au "Bois Harlé" à Longueil-SainteMarie (Oise). Revue archéologique de Picardie 8 (1), 159-164.

Levine, M.A., 2005. Abnormal thoracic vertebrae and the evolution of horse husbandry. Archaeofauna 14, 93-109.

Levine, M.A., Bailey, G.N., Whitwell, K.E., Jeffcott, L.B., 2000. Palaeopathology and horse domestication: the case of some Iron Age horses horn the Altai Mountains, Siberia. In: Bailey, G., Charles, R., Winder, N. (Eds.), Human Ecodynamics. Symposia of the Association for Environmental Archaeology. Oxbow Books, Oxford, pp. 123-133.

Liesau, C., 1998. IV el Soto de Medinilla. El Soto de Medinilla: faunas de mamíferos de la Edad del Hierro en el Valle del Duero (Valladolid, España). Archaeofauna 7.

Liesau, C., 2005. Arqueozoología del caballo en la antigua Iberia. Gladius XXV, 187-206.

Lignereux, Y., Peters, J., Perrin, N., Gruat, P., 1998. Un cheval gallo-romain inhumé dans le cimetière du site de Notre-Dame du Bon Accueil (IIe-IIIe siècle après J.-C., Rodez). Rev. Med. Vet. 149 (5), 379-386.

López Cachero, F.J., 2007. Sociedad y economía durante el Bronce final y la Primera edad del Hierro en el noreste peninsular: una aproximación a partir de las evidencias arqueológicas. Trab. Prehist. 64 (1), 99-120.

López Cachero, F.J., Rovira, M.C., 2012. El Món funerari a la depressió prelitoral catalana entre el bronze final i la primera edat del ferro: ritual i dinamisme social a partir de registre arqueològic. In: Rovira, M.C., López-Cachero, F.J., Maziere, F. (Eds.), Les necròpolis d'incineració entre l'Ebre i el Tíber (segles IX-VI a. C.). Monografies de Museu d'Arqueologia de Catalunya-Barcelona 14, Barcelona, pp. 37-55.

López Cachero, J., Albizuri, S., Majó, T., Carlús, X., Oliva Poveda, M., Palomo, A., Rodriguez, A., Terrats, N., 2019. Depósitos de caballo en Can Roqueta (Sabadell, Barcelona) durante el Bronce Final y la Primera Edad del Hierro. In: Congreso de Prehistoria y Protohistoria del Mediterráneo Occidental, Museu de Menorca, 27-30 abril 2017, (in press).

López-Cachero, F.J., 2014. Necròpolis d'incineració. Tombes i pràctiques de dipòsit funerari a finals de l'edat del bronze i principis de l'edat del ferro al nord-est peninsular, in: La transició bronze final -1a edat del ferro en els Pirineus i territoris veïns. XII Col-loqui Internacional d'Arqueologia de Puigcerdà, Institut d'Estudis Ceretans, Puigcerdà, pp. 329-370.

Makarewicz, C.H.A., Winter-Schuh, C.H., Byerly, H., Houle, J.L., 2018. Isotopic evidence for ceremonial provisioning of Late Bronze age khirigsuurs with horses from diverse geographic locales. Quat. Int. 1-12.

Michel, C., 2004. The perdum-mule, a mount for distinguished persons in Mesopotamia during the first half of the second millennium BC. In: Santillo Frizell, B. (Ed.), Man and Animal in Antiquity Rome. Swedish Institute in Rome, pp. 190-200.

Ministerio de Agricultura, Pesca y Ganadería, 2003. Estudio y caracterización del sector equino en España. Ministerio de Agricultura, pesca y Ganadería, Tragsega.

Minniti, C., Valenzuela-Lamas, S., Evans, J., Albarella, U., 2014. Widening the market. Strontium isotope analysis on cattle teeth from Owslebury (Hampshire, UK) highlights changes in livestock supply between the Iron Age and the Roman period. J. Archaeol. Sci. 42, 305-314.

Morales Muñiz, A., 1992. Estudio de la fauna del yacimiento calcolítico de «Las Pozas» (Casaseca de Las Chanas, Zamora): campaña 1979. Boletín del Seminario de Estudios de Arte y Arqueología 58, 65-96.

Morris, J., 2008. Associated bone groups; one archaeologist's rubbish is another's ritual deposition. In: Davis, O., Waddington, K., Sharples, N. (Eds.), Changing Perspectives on the First Millennium BC. Oxbow, Oxford, pp. 83-98.

Morris, J., 2011. Investigating animal burials. Ritual, mundane and beyond. British archaeological reports, British series 535, Archaeopress, Oxford.

Nadal, J., Albizuri, S., Maroto, J., 2010. Els orígens del burro domèstic a la Mediterrània i a la península Ibèrica segons les dades arqueològiques. In: Bosch, E., Comas, P., Maroto, J. (Eds.), La recuperació del burro català. Aspectes culturals i biològics. Quaderns 28. CECB, Banyoles, pp. 37-56.

Nieto, A., Gardeisen, A., Junyent, E., López, J.B., 2010. Inhumations de fotus d'équidés dans la forteresse du premier âge du Fer de Els Vilars (Arbeca Catalogne). In: Gardeisen, A., Furet, E., Boulbes, N. (Eds.), Histoire d'équidés, des textes, des images et des os. Monographies d'Archéologie Médierranéenne, Hors série; 4, Lattes, pp. 125-148.

Nieto, A., López, J.B., Junyent, E., 2016. Nuevos datos sobre la presencia del caballo en las comunidades protohistóricas del Valle del Segre, in: O Cavalo e o Touro na Préhistória e na História. Actas del I Congresso Internacional Equuspolis, GolegãChamusca. Centro Português de Geo-História e Pré-História (CPGP), 2013, pp. 117-134.

Nuviala, P., Nowell, G., Ughetto, J., Balasse, M., 2014. L'origine des chevaux du site du Mormont (canton de Vaud, Suisse): l'apport des isotopes du carbone, de l'oxygène et du strontium. In: Barral, $\mathrm{Ph}$ ( $\mathrm{Ed}$.), Les Celtes et le Nord de l'Italie. Actes du $36 \mathrm{e}$ 
colloque international de l'AFEAF. AFEAF et Revue Archéologique de l'Est, Dijon, pp. 603-609.

Piggot, S., 1962. Heads and hoofs. Antiquity XXXVI, 110-118.

Pin, C., Briot, D., Bassin, C., Poitrasson, F., 1994. Concomitant separation of strontium and samarium-neodymium for isotopic analysis in silicate samples, based on specific extraction chromatography. Anal. Chim. Acta 298, 209-217.

Poplin, T., 1976. Remarques théoriques et pratiques sur les unités utilisées dans les études d'ostéologie quantitative, particulièrement en archéologie préhistorique. In: Problèmes d'interprétation ethnographique des vestiges osseux, Section méthodologie, IXème Congrès UISPP, Nice, pp. 1-16.

Price, T.D., Burton, J.H., Bentley, R.A., 2002. The characterization of biologically available strontium isotope ratios for the study of prehistoric migration. Archaeometry 44 (1), 117-135.

Quesada, F., 2004. La alzada del caballo antiguo: un estado de la cuestión aplicado a la Edad del Hierro de la Península Ibérica. CuPAUAM 30, 77-89.

Rooney, J.R., 1997. Equid Palaeopathology. Journal of Equine Veterinary Science 17, 430-446.

Rovira, M.C., López-Cachero, F.J., 2016. Las fíbulas serpentiformes de Cataluña en el marco del Mediterráneo noroccidental. In: De Chazelles, Cl.A., Schwaller, M. (Eds.), Vie quotidienne, tombes et symbols des sociétés protohistoriques de Méditerranée nord-occidentale. Mélanges offerts à Bernard Dedet, vol. 2, Monographies d'Archéologie Méditerranéenne, Hors série n7, Lattes, pp. 705-719.

Rovira, M.C., Hunt, M., Montero, I., Rovira, S., López Cachero, F.J., 2008. Caracterización isotópica de bronces de la necrópolis protohistórica de Can Piteu-Can Roqueta (Sabadell, Barcelona). VII Congreso Ibérico de Arqueometría, Madrid 2007, 448-457.

Santanach, P., Casas, J.M., Gratacós, O., Liesa, M., Muñoz, J.A., Sàbat, F., 2011. Variscan and Alpine structure of the hills of Barcelona: geology in an urban area. J. Iber. Geol. 37 (2), 121-136.
Scheeres, M., Knipper, C., Hauschild, M., Schönfelder, M., Siebel, W., Vitali, D., Pare, C., 2013. Evidence for "Celtic migrations"?. Strontium isotope analysis at the early La Tène (LT B) cemeteries of Nebringen (Germany) and Monte Bibele (Italy). J. Archaeol. Sci. 40 (10), 3614-3625.

Thomas, R., 2017. The zooarchaeology of animal 'care'. In: Powell, L., Southwell-Wright, W., Gowland, R. (Eds.), Care in the Past: Archaeological and Interdisciplinary Perspectives. Oxbow Books, Oxford, pp. 169-188.

Toots, H., Voorhies, M.R., 1965. Strontium in fossil bones and the reconstruction of food chains. Science 149 (3686), 854-855.

Valenzuela-Lamas, S., Orengo, H.A., Bosch, D., Pellegrini, M., Halstead, P., Nieto-Espinet, A., Trentacoste, A., Jiménez-Manchón, S., López-Reyes, D., Jornet-Niella, R., 2018. Shipping amphorae and shipping sheep? Livestock mobility in the north-east Iberian peninsula during the Iron Age based on strontium isotopic analyses of sheep and goat tooth enamel. PLoS One 13 (10), e0205283.

Viner, S., Evans, J., Albarella, U., Pearson, M.P., 2010. Cattle mobility in prehistoric Britain: strontium isotope analysis of cattle teeth from Durrington Walls (Wiltshire, Britain). J. Archaeol. Sci. 37, 2812-2820.

Voerkelius, S., Lorenz, G.D., Rummel, S., Quetel, C.R., Heiss, G., Baxter, M., Brach-Papa, C., Deters-Itzelsberger, P., Hoelzl, S., Hoogewerff, J., Ponzevera, E., Van Bocxstaele, M., Ueckermann, H., 2010. Strontium isotopic signatures of natural mineral waters, the reference to a simple geological map and its potential for authentication of food. Food Chem. 118 (2010), 933-940.

Von den Driesch, A., 1976. A Guide to the Measurement of Animal Bones From Archaeological Sites. Peabody Museum of Archaeology and Ethnology, Bulletin 1. Harvard University Press.

Waterman, A.J., Peate, D.W., Silva, A.M., Thomas, J.T., 2014. In search of homelands: using strontium isotopes to identify biological markers of mobility in late prehistoric Portugal. J. Archaeol. Sci. 42, 119-127. 